\title{
Boccaccio's Poetic Anthropology: Allegories of History in the Genealogie deorum gentilium libri
}

\author{
By David Lummus
}

\begin{abstract}
When Giovanni Boccaccio undertook to compile the myths of Greco-Roman antiquity in the mid-fourteenth century, he was working within a long tradition of medieval commentaries on Ovid's mythological works (principally the Metamorphoses and the Fasti) and mythographical compendia, such as Alberic of London's De deis gentium. ${ }^{1}$ His Genealogie deorum gentilium libri, on which
\end{abstract}

Earlier versions of this essay were presented at the Stanford Humanities Center in October 2007 and at Yale University in February 2008. I would like to thank the participants at those colloquia and also Susanna Braund, Hans Ulrich Gumbrecht, Robert Harrison, Seth Lerer, Giuseppe Mazzotta, Jeffrey Schnapp, and the anonymous readers at Speculum for their comments. I have also benefited from the comments of the students of my mythography seminar at Yale, whom I would like to thank.

\begin{abstract}
${ }^{1}$ Major mythographies with which Boccaccio was familiar include Fulgentius's Mythologiae, in Opera, ed. Rudolf Helm (Leipzig: Teubner, 1898), 1-80; the Third Vatican Mythographer, or Alberic of London's De deis gentium, in Scriptores rerum mythicarum Latini tres Romae nuper reperti, ed. Georgius Henricus Bode (Celle: Schulze, 1834; repr., Hildesheim: Olms, 1968), 152-256; Isidore of Seville's eighth book of the Etymologiae, in Etimologie o origini, ed. Angelo Valastro Canale, 2 vols. (Turin: UTET Libreria, 2006), 1:627-702, esp. 671-702; and, although Boccaccio does not cite it, perhaps Giovanni del Virgilio's Allegoriae, edited by Fausto Ghisalberti in "Giovanni del Virgilio, espositore delle 'Metamorfosi,", Il giornale dantesco 34, n.s. 4 (1932): 1-110, at 43-107, subsequently reprinted as a book with the same title and pagination (Florence: Olschki, 1933). On the mythographical tradition in the Middle Ages and Renaissance generally see Jean Seznec, La survivance des dieux antiques: Essai sur le rôle de la tradition mythologique dans l'humanisme et dans l'art de la Renaissance, Studies of the Warburg Institute 11 (London: Warburg Institute, 1940; repr., Paris: Flammarion, 1980); Jane Chance, Medieval Mythography, 2 vols. (Gainesville: University Press of Florida, 1994-2001); Leonard Barkan, The Gods Made Flesh: Metamorphosis and the Pursuit of Paganism (New Haven: Yale University Press, 1986); and Don Cameron Allen, Mysteriously Meant: The Rediscovery of Pagan Symbolism and Allegorical Interpretation in the Renaissance (Baltimore: Johns Hopkins University Press, 1970). For bibliography on mythography as a part of the iconographical tradition of the Middle Ages see R.E. Kaske, Medieval Christian Literary Imagery: A Guide to Interpretation, Toronto Medieval Bibliographies 11 (Toronto: University of Toronto Press, 1988), 104-29. On the tradition of commentaries on Ovid's texts during the late Middle Ages see Ralph J. Hexter, Ovid and Medieval Schooling: Studies in Medieval School Commentaries on Ovid's "Ars amatoria," "Epistulae ex Ponto," and "Epistulae Heroidum,” Münchener Beiträge zur Mediävistik und Renaissance-Forschung 38 (Munich: Arbeo-Gesellschaft, 1986); and Hexter, "Medieval Articulations of Ovid's 'Metamorphoses': From Lactantian Segmentation to Arnulfian Allegory," Mediaevalia 13 (1987): 63-82; but also the more recent Frank T. Coulson and Bruno Roy, Incipitarium Ovidianum: A Finding Aid for Texts Related to the Study of Ovid in the Middle Ages and Renaissance, Publications of the Journal of Medieval Latin 3 (Turnhout: Brepols, 2000); and Ralph J. Hexter, "Ovid in the Middle Ages: Exile, Mythographer, and Lover," in Brill's Companion to Ovid, ed. Barbara Weiden Boyd (Leiden: Brill, 2002), 413-42. For the contents of Boccaccio's library see Antonia Mazza, "L'itinerario della 'Parva libraria' in Santo Spirito e la biblioteca del Boccaccio," Italia medioevale e umanistica 9 (1966): 1-74; and Mostra di manoscritti, documenti, e edizioni: Firenze,
\end{abstract}


he worked until the final years of his life, ${ }^{2}$ also falls within the traditions of biblical exegesis and of philosophical commentary on texts, such as Boethius's De consolatione philosophiae and Virgil's Aeneid. ${ }^{3}$ The complex and eclectic nature of Boccaccio's learning, however, along with the antimodern organizational structure of the treatise, has led to the underestimation of its importance in the history of medieval and Renaissance approaches to ancient myth. ${ }^{4}$ As Charles

Biblioteca Medicea Laurenziana, 22 maggio-31 agosto 1975, 2 vols. (Certaldo: Comitate promotore, 1975).

2 There are two modern editions of the text, both out of print and both still useful: Vincenzo Romano, ed., Genealogie deorum gentilium libri, Scrittori d'Italia 200, 2 vols. (Bari: Laterza, 1951); and Vittorio Zaccaria, ed., Genealogie deorum gentilium, in Tutte le opere di Giovanni Boccaccio, 7-8 (Milan: Mondadori, 1998). Hereafter I cite only the more accurate edition by Zaccaria and refer to it as Genealogie, followed by the book, chapter, and paragraph numbers, the first two of which are common to all editions. Unless otherwise noted, all translations are my own. The first full English translation of the Genealogie is currently being completed by Jon Solomon for Harvard University Press's I Tatti Renaissance Library. Volume 1, which contains the first five books, was released in May 2011, not in time for me to consult it in the preparation of this article: Giovanni Boccaccio, Genealogy of the Pagan Gods, 1: Books I-V, trans. Jon Solomon, Tatti Renaissance Library 46 (Cambridge, MA: Harvard University Press, 2011). On the chronology of the composition of the Genealogie and the manuscript tradition see Vittorio Zaccaria, "Nota al testo," in Genealogie, 8:159299. Zaccaria dates the final manuscript (known as Vulg.) to after April 1372, three years before Boccaccio's death in December 1375 (8:1594), whereas the first complete copy (known as A), an autograph in the margins of which Boccaccio added material, was completed between 1360 and 1375 . Zaccaria's introduction to the edition $(7: 13-42)$ is also very useful in establishing Boccaccio's many diverse sources, some of which I mention in the previous note.

${ }^{3}$ Boccaccio frequently alludes to the commentary tradition, such as Fulgentius's allegorical reading of the Aeneid, as well as to the philosophical commentaries coming out of Chartres, including the commentaries on Martianus Capella's De nuptiis Philologiae et Mercurii and on the Aeneid. For his early engagement with the Chartrians see Steven Grossvogel, Ambiguity and Allusion in Boccaccio's Filocolo, Biblioteca dell" “Archivum Romanicum,” 1st ser. 248 (Florence: Olschki, 1992). On myth in the Chartrian commentaries and philosophical poetry see Winthrop Wetherbee, Platonism and Poetry in the Twelfth Century: The Literary Influence of the School of Chartres (Princeton: Princeton University Press, 1972); Brian Stock, Myth and Science in the Twelfth Century: A Study of Bernard Silvester (Princeton: Princeton University Press, 1972); Paule Demats, Fabula: Trois études de mythographie antique et médiévale, Publications romanes et françaises 122 (Geneva: Droz, 1973); Peter Dronke, Fabula: Explorations into the Uses of Myth in Medieval Platonism, Mittellateinische Studien und Texte 9 (Leiden: Brill, 1974); A.J. Minnis, A.B. Scott, and David Wallace, eds., Medieval Literary Theory c. 1100-c. 1375: The Commentary Tradition (Oxford: Oxford University Press, 1988), 113-64; Winthrop Wetherbee, "Philosophy, Commentary, and Mythic Narrative in Twelfth-Century France," in Interpretation and Allegory: Antiquity to the Modern Period, ed. Jon Whitman, Brill's Studies in Intellectual History 101 (Leiden: Brill, 2000), 211-30; and Chance, Medieval Mythography, 2.

${ }^{4}$ Criticism on the Genealogie is relatively limited given the importance of the text. The first major works on the treatise date to the late nineteenth century and are still valuable, though a complete reading of the treatise has never been proposed. See Attilio Hortis, Studj sulle opere latine del Boccaccio (Trieste: Dase, 1879); and Oskar Hecker, Boccaccio-Funde (Braunschweig: Westermann, 1901). For more recent overviews of the Genealogie see Cornelia Catlin Coulter, "The Genealogy of the Gods," in Christabel Forsyth Fiske, ed., Vassar Mediaeval Studies (New Haven: Yale University Press, 1923), 317-41; Thomas Hyde, "Boccaccio: Genealogies of Myth,” PMLA 100 (1985): 737-45; Zaccaria, Genealogie, 7:13-42, reprinted in Vittorio Zaccaria, Boccaccio narratore, storico, moralista, e mitografo (Florence: Olschki, 2001); Henry David Jocelyn, "Giovanni Boccaccio's Interpretations of the Graeco-Roman Myths and the Constraints and Impulses of His Own Times,” in Hans-Jürgen Horn and Hermann Walter, eds., Die Allegorese des antiken Mythos, Wolfenbütteler Forschungen

Speculum 87.3 (July 2012) 
Osgood's partial translation of the work demonstrates, the focus of critics has been limited to the final two books of the treatise, in which Boccaccio defends both poetry and his work from detractors. ${ }^{5}$ The fourteenth and fifteenth books of the Genealogie have been by far the most long-lived sections of the work. The straightforward defense of poetry through recourse to the topos of the poeta theologus places the work in a historical continuum that leads from Albertino Mussato and Francesco Petrarca to Coluccio Salutati, Marsilio Ficino, and Angelo Poliziano, not to mention the poetic theorists of the English Renaissance, such as Sir Philip Sidney. ${ }^{6}$

The Genealogie was recognized in Boccaccio's own time and in the century that followed its completion as Boccaccio's major contribution to the study of antiquity that dominated fifteenth-century Italy. ${ }^{7}$ The lack of critical engagement

75 (Wiesbaden: Harrassowitz, 1997), 253-66; Giuseppe Mazzotta, "Boccaccio: Mythographer of the City," in Whitman, ed., Interpretation and Allegory, 349-64; and Manlio Pastore Stocchi, "Giovanni Boccaccio: La 'Genealogia deorum gentilium.' Una novità mitografica,” in Gian Carlo Alessio, ed., Il mito nella letteratura italiana, vol. 1: Dal medioevo al Rinascimento, Biblioteca Morcelliana 1 (Brescia: Morcelliana, 2004), 229-46. On the sources of the Genealogie see Henry David Jocelyn, "The Sources of Boccaccio's 'Genealogiae deorum gentilium libri' and the Myths about Early Italy," in Luisa Rotondi Secchi Tarugi, ed., Il mito nel Rinascimento, Caleidoscopio 4 (Milan: Nuova orizzonti, 1993), 7-26; and Manlio Pastore Stocchi, "Da Crisippo al Boccaccio," in Roberto Cardini, Eugenio Garin, Lucia Cesarini Martinelli, and Giovanni Pascucci, eds., Tradizione classica e letteratura umanista: Per Alessandro Perosa, Humanistica 3-4, 2 vols. (Rome: Bulzoni, 1985), 1:139-58.

${ }^{5}$ Charles G. Osgood's translation, Boccaccio on Poetry (Princeton: Princeton University Press, 1930), cited here from the 1956 reprint (Library of Liberal Arts 82 [New York: Liberal Arts Press]), was for many years the most complete English version of the work, though the I Tatti Library translation will soon supplant it. Osgood translated only the first proem and the fourteenth and fifteenth books. The defense of poetry has been treated amply in criticism; see, e.g., Hortis, Studj, 175-97; Gregory B. Stone, The Ethics of Nature in the Middle Ages: On Boccaccio's Poetaphysics (New York: St. Martin's Press, 1998), 43-45 (on poetry and philosophy), 92-95 (on the origin of poetry), and 141-56 (on the truth claims of poetry); Giovanni Gullace, "Medieval and Humanistic Perspectives in Boccaccio's Concept and Defense of Poetry," Mediaevalia 12 (1989 [for 1986]): 226-48; Anna Cerbo, Metamorfosi del mito classico da Boccaccio a Marino, Letteratura Italiana 6 (Pisa: ETS, 2001), 13-29; Pastore Stocchi, "Giovanni Boccaccio," 240-45; Étienne Gilson, "Poésie et vérité dans la 'Genealogia' de Boccace," Studi sul Boccaccio 2 (1964): 253-82; Eugenio Garin, Medioevo e rinascimento: Studi e ricerche, Biblioteca di Cultura Moderna 506 (Bari: Laterza, 1954), 66-89; and Osgood, Boccaccio on Poetry, xi-xlix. On Boccaccio's theory of allegory in book 14 of the Genealogie see James C. Kriesel, “The Genealogy of Boccaccio's Theory of Allegory,” Studi sul Boccaccio 36 (2009): 197-226.

${ }^{6}$ On the tradition of the poeta theologus in fourteenth-century Italy see Giorgio Ronconi, Le origini delle dispute umanistiche sulla poesia (Mussato e Petrarca), Strumenti di Ricerca 11 (Rome: Bulzoni, 1976); and Charles Trinkaus, In Our Image and Likeness: Humanity and Divinity in Italian Humanist Thought (Chicago: University of Chicago Press, 1970; repr., Notre Dame: University of Notre Dame Press, 1995), 683-721.

7 The Genealogie, with twenty-seven manuscripts, saw ten Latin editions between 1472 and 1532 and twelve editions in Italian translation. It was also translated into French and Spanish soon afterward. See Ernst H. Wilkins, "The Genealogy of the Editions of the 'Genealogia deorum," Modern Philology 17 (1919): 423-38. Poliziano possessed a copy of the fourteenth and fifteenth books in his notebooks, on which see Vittore Branca, Poliziano e l'umanesimo della parola, Saggi 655 (Turin: Einaudi, 1983). Albert Ascoli has noted the importance of Boccaccio's Genealogie for Ludovico Ariosto's Orlando Furioso, in Ariosto's Bitter Harmony: Crisis and Evasion in the Italian Renaissance

Speculum 87.3 (July 2012) 
with the first thirteen books of the treatise must in large part be due to their collective length, the difficulty presented by the work's structure, and the common opinion that the treatise is but another repetition of a common, euhemeristic engagement with ancient myth. ${ }^{8}$ Disparagement of the Genealogie began in the sixteenth century, when the difficulties presented by its organization and some of its more imaginative interpretations caused frustration among those who desired to popularize ancient myths among modern artists and the intelligentsia of the Ferrarese court. ${ }^{9}$ Surely a problem as well was the work's almost entire lack of Greek sources, sources that by the sixteenth century had become central to the studia bumanitatis and to contemporary imitations of the classical. ${ }^{10}$ The

(Princeton: Princeton University Press, 1987). The centrality of the Genealogie in the fifteenthcentury biographies of the author is exemplified by Leonardo Bruni (1369-1444), who wrote, "Dell'opere sue scritte in latino, la Genealogia deorum tiene il principato," Notizia del Boccaccio e parallelo dell'Alighieri e del Petrarca, in Le vite di Dante e del Petrarca, ed. Antonio Lanza, Pagine d'Archivio 2 (Rome: Archivio Guido Izzi, 1987), 61.

${ }^{8}$ Seznec, Survivance, 202 dismissed the Genealogie as "malgré quelques symptomes d'un esprit nouveau, encore au passé médiéval,” importing his judgment from scholars, such as Hortis, who defined the work's critical reception. More recently John Mulryan and Steven Brown have written that "like the earlier mythographers, he [Boccaccio] is uncritical of his sources ... and unhistorical in his approach to the study of etymology," Natale Conti’s "Mythologiae," ed. John Mulryan and Steven Brown, Medieval and Renaissance Texts and Studies 316 (Tempe: Arizona Center for Medieval and Renaissance Studies, 2006), xxx.

${ }^{9}$ Mulryan and Brown, Natale Conti's Mythologiae, xxx continue their critique from the point of view of sixteenth-century poets and artists, stating that “Boccaccio's most serious weaknesses are his genealogical approach ... and his almost complete ignorance of Greek.... In short, Boccaccio provides the reader with a random account of miscellaneous gods and the different sacrifices that were attributed to them, but not in a form that can be easily referred to by the Renaissance poet or artist."

${ }^{10}$ Ironically, one of the major accomplishments of the Genealogie was, at least for Boccaccio, the inclusion of Greek sources, which he defends in the last book of the treatise (Genealogie 15.7.4, trans. Osgood, 119):

"Ast ego in hoc Latinitati compatior, que sic omnino greca abiecit studia, ut etiam non noscamus caracteres licterarum. Nam, etsi sibi suis sufficiat licteris, et in eas omnis occiduus versus sit orbis, sociate Grecis lucidiores procul dubio apparerent. Nec preterea omnia secum a Grecia veteres traxere Latini: multa supersunt, et profecto nobis incognita, quibus possemus scientes effici meliores.”

(I am sorry, then, for Latin learning, if it has so completely rejected the study of Greek that we do not even recognize the characters. Though Latin literature be sufficient unto itself, and enjoys the exclusive attention of the whole western world, yet without question it would gain much light through an alliance with Greek. Besides the ancient Latin writers have not by any means appropriated all that is Greek. Much yet remains unrevealed to us, and much by knowledge of which we might profit greatly.)

This is surely a response to Petrarch's idea of Latin's superiority to Greek, as seen in his statement to Giovanni Dondi da Padova: "Denique Grecos et ingenio et stilo frequenter vicimus et frequenter equavimus, imo, siquid credimus Ciceroni, semper vicimus ubi annisi sumus" ("In short, we frequently overcame the Greeks in talent and style, and we frequently equaled them; or rather, if we trust Cicero, we always won whenever we competed"); Lettres de la vieillesse = Rerum senilium 12.2.71, ed. Elvira Nota and Ugo Dotti, 4 vols. (Paris: Belles Lettres, 2002); trans. Aldo S. Bernardo, Letters of Old Age, 2 vols. (Baltimore: Johns Hopkins University Press, 1992), 2:473. In his discussion of Boccaccio's life Giannozzo Manetti (1396-1459) notes that the Florentine humanists owe the study of Greek to Boccaccio's initiative: “De vita et moribus trium illustrium poetarum Florentinorum," in Le vite di

Speculum 87.3 (July 2012) 
eclecticism of Boccaccio's sources and the apparent irrationality of his approach caused the work to become categorized as outdated in the history of thought on myth. In this essay I propose to revisit Boccaccio's approach to myth and show how its medievalism is precisely what renders it modern. Boccaccio's medieval eclecticism, so disparaged by historians of Renaissance art, such as Jean Seznec, is the link to his radical modernity. He makes use of medieval thought processes, such as genealogy, allegorical interpretation, euhemerism, and the poeta theologus, and arrives at what might be described as an anthropological understanding of myth as a cultural artifact that develops over time. ${ }^{11}$

In the three proems to the Genealogie addressed to the work's patron, King Hugh IV of Cyprus, ${ }^{12}$ Boccaccio does not offer a precise methodological framework for his work, yet he makes his methodology clear through various side remarks to his patron and through the early examples of mythological exegesis. The lack of a clear authorial definition of method has led Vittorio Zaccaria, the most prominent editor of the text, to assert that Boccaccio had no well-defined method of interpretation. ${ }^{13}$ Zaccaria acknowledged a dominant historicism in Boccaccio's interpretation of myth, yet for him the method is not clearly enough defined to make Boccaccio a self-conscious modern thinker. Indeed, to think of his method as set forth scientifically and rationally would be entirely anachronistic. Nevertheless, the historical method and genealogical structure that guide his work allow Boccaccio to see the stories of the pagan gods as having developed in time according to the generations of humankind. The gods were the first creations of the human mind, metaphors for the human condition that gradually accrued multiple meanings as time passed and humanity's place in nature changed. Boccaccio sees myth as unveiling its own historicity as it veils ethical and natural truths. Through a historical understanding of myth, he is able to reconnect these truths to his contemporary, Christian world without eliding historical difference.

Dante, Petrarca e Boccaccio scritte fino al secolo decimosesto, ed. Angelo Solerti (Milan: Vallardi, 1904), 684-93. As Mulryan and Brown point out, however, in the sixteenth century mythographers had available more advanced linguistic capabilities and easier access to Greek texts. These circumstances led to a desire to reread and reorganize ancient myth for a new generation. See Mulryan and Brown, Natale Conti's Mythologiae, xxv-xlvi. Lilio Gregorio Giraldi attacked Boccaccio's genealogical structure in his dedicatory letter to Ercole II d'Este, duke of Ferrara. He wrote that although Boccaccio was learned for his time and a master of the vernacular, he was unlearned in Latin and even less in Greek. See "Epistola nuncupatoria," Historia deorum gentilium, in Opera omnia, ed. Johann Faes, Paul Colomiès, and Johannes Jens, 2 vols. (Leiden: Hack, 1696), 1:20-21.

${ }^{11}$ On genealogy in the Middle Ages see Howard Bloch, "Genealogy as a Medieval Mental Structure and Textual Form," in Hans Ulrich Gumbrecht, Ursula Link-Heer, and Peter-Michael Spangenberg, eds., La littérature historiographique des origines à 1500, vol. 1, Grundriss der romanischen Literaturen des Mittelalters 11 (Heidelberg: Winter, 1986), 135-56. On the importance of the genealogical "mindset" to Boccaccio's organization of his work see Ernest Hatch Wilkins, The Trees of the "Genealogia deorum" of Boccaccio (Chicago: The Caxton Club, 1923); and Mazzotta, "Boccaccio," 355-56 and 360-61.

${ }^{12}$ On Boccaccio's dedication of the work to Hugh see Zaccaria's note to the first proem, Genealogie, 8:1611 n. 1; and Hortis, Studj, 158-61.

${ }^{13}$ Boccaccio's historicism is well noted, although discounted, in the criticism on the Genealogie. See Hortis, Studj, 166-70; and Zaccaria, Genealogie, 7:18-25. See also, however, Mazzotta, "Boccaccio," in which he briefly argues for a radically historicist humanism in the Genealogie.

Speculum 87.3 (July 2012) 
The reduction of myths to stories about the idolatry of important men, or euhemerism, was a popular method of interpretation throughout the Middle Ages. It stemmed from texts, such as Cicero's De natura deorum, Lactantius's Divinae institutiones, and Augustine's De civitate Dei, but it was also available as an interpretative apparatus via Isidore of Seville's popular Etymologiae. ${ }^{14}$ When Fulgentius was doubtful about possible allegorical meanings, he, too, resorted to euhemerism to explain the meaning behind myths. Indeed, the historical interpretation was often taken for granted as a way of emptying myth of the meaning it had held in a pagan, polytheistic system of belief..$^{15}$ In the process of interpretation, euhemerism was the first step that allowed for the reinterpretation of a story in a Christian key. Mythographers, such as the First and Second Vatican Mythographers, Alberic of London, Arnulf of Orléans, and John of Garland limit themselves to brief, rare mentions of the literal or historical sense of a myth only to pass on to philosophical interpretations. There was no reason to delve into the historical context of the poetic creations; their interests lay in salvaging the figures of ancient religion by removing them from their historical context.

This general use of euhemerism is illustrated by Fulgentius in the first three chapters of his Mythologiae. He opens with a description of the beginning of idolatry similar to those presented by Lactantius and Isidore, then makes Saturn into a deified man, but by the third exposition, he is already speaking of the astrological import of Neptune. ${ }^{16}$ The fifth-century mythographer no longer has any

\footnotetext{
${ }^{14}$ On the historical tradition of mythography from its origins in antiquity through the Renaissance see Seznec, Survivance, 11-36. On euhemerism in the Middle Ages see John Daniel Cooke, "Euhemerism: A Mediaeval Interpretation of Classical Paganism," Speculum 2 (1927): 396-410, which traces Isidore's influence through medieval mythography and especially in the gesta and chronicles traditions; Paul Alphandéry, "L'Euhémérisme et les débuts de l'histoire des religions au moyen âge," Revue de l'histoire des religions 109 (1934): 5-27, which finds a sort of protoreligious history in the chronicles of medieval France; Arthur B. Ferguson, Utter Antiquity: Perceptions of Prehistory in Renaissance England, Duke Monographs in Medieval and Renaissance Studies 13 (Durham: Duke University Press, 1993), 13-22; and Gian Carlo Alessio, "La letteratura latina medievale: Gli dèi nel medioevo, fra evemerismo e allegoria," in Alessio, ed., Il mito nella letteratura italiana, 63-77. On Petrarch's thoughts on and uses of the method see Carlo Vecce, "Francesco Petrarca: La rinascita degli dèi antichi," ibid., 191-92. On Boccaccio's thoughts on and uses of it see Pastore Stocchi, "Giovanni Boccaccio," 232-34. In the English context Ralph Higden's Polychronicon represents an example of how the euhemeristic tradition was being utilized to bridge the gap between ancient and modern politics. See, e.g., Polychronicon, ed. Churchill Babington, 9 vols. (London: Longman, 1865), 2:9, 281-82, and 364. On Pierre Bersuire's limited use of the historical approach to myth see Fausto Ghisalberti, “L'Ovidius moralizzatus di Pierre Bersuire,” Studi romanzi 23 (1933): 5-136, esp. 38-42.

${ }^{15}$ On the use of euhemerism by the Church fathers as a critique of the falsa religio of the pagans see Lactantius, Divinarum institutionum libri septem, vol. 1: Libri I et II, ed. Eberhard Heck and Antonie Wlosok, Bibliotheca Scriptorum Graecorum et Romanorum Teubneriana 1265 (Munich: Teubner, 2005), 1.14-15; and Augustine, De civitate Dei contra paganos, ed. and trans. George E. McCracken, Loeb Classical Library, 7 vols. (Cambridge: Harvard University Press, 1957), 8.26. For Isidore see Etymologiae 8.11.1 and 29 and his explanation of Bel in 9.23-26. On the role of Isidore in defining medieval euhemerism see Cooke, "Euhemerism," 403. Cf. Seznec, Survivance, 18.

${ }^{16}$ Fulgentius attributes the origin of idolatry primarily to grief, but he also mentions fear as another possible cause; see Mythologiae 1.1. Lactantius, writing a century before Fulgentius, follows Cicero's De natura deorum (2.62 and 3.50) and attributes the beginning of idolatry to king worship. He also mentions Cicero's own idolatry of his daughter as a result of grief; see Divinae institutiones 1.15. Isidore, writing a century after Fulgentius, offers a much more anthropological point of view,
} 
need to contextualize the "falsa religio" ("false religion") of the pagans in order to reinterpret it in a scientific or philosophical manner. As he writes in his introduction to the text, his intent is to bury the fables of the poets in order to find what is mystical in them: "quo sepulto mendacis Greciae fabuloso commento quid misticum in his sapere debeat cerebrum agnoscamus" ("once the fictional invention of the lying Greeks has been disposed, I may infer what allegorical significance one should understand in such matters"). ${ }^{17}$ The euhemeristic method returns only when Fulgentius must respond to highly charged episodes, such as the escapades of Jupiter, which had been condemned by Augustine. ${ }^{18}$ Such employment of the euhemeristic method continued in medieval mythography through the fourteenth century. ${ }^{19}$

Although the mythographers of the fourteenth century continue rather unproblematically the tradition of allegorizing myth after a euhemeristic deconstruction of polytheism, commentaries on Ovid's Metamorphoses do offer a more developed attention to the historical contextualization of the poet. As Alastair Minnis and Alexander Scott have pointed out in their anthology of medieval literary theory, Giovanni del Virgilio makes Ovid's intention central to the poem's meaning by defining the poet himself as its efficient, or moving, cause. ${ }^{20}$ Del Virgilio follows in the tradition of literalist and historicist interpretations of the Gospels, such as those of Hugh of St. Victor, Peter Abelard, and Nicholas of Lyre, which in different ways find the intentionality of the human writer of tantamount

interweaving idol worship in the Hebrew tradition with that of the Greco-Roman tradition; see Etymologiae 8.11.1-28.

${ }^{17}$ Fulgentius, Mythologiae 1.21, trans. George Whitbread, Fulgentius the Mythographer (Columbus: Ohio State University Press, 1971), 45.

${ }^{18}$ As an example see Fulgentius's interpretations of Ganymede and Europa as ships with an eagle or a bull respectively on the prow (Mythologiae 1.20). For Augustine's famous condemnation of Jupiter's licentiousness see, e.g., De civitate Dei 7.26, although Augustine takes to task the Romans' worship of Jupiter across books 4-8.

${ }^{19}$ Arnulf of Orléans, John of Garland, and Giovanni del Virgilio follow Fulgentius's use of euhemerism as the method of last resort. As textual commentators, they are interested only generally in connecting the intentionality of a historical poet, Ovid, to the ethical meaning behind myths. Both John of Garland and Giovanni del Virgilio frequently follow Arnulf's lead in their commentaries and accessus, in which there is a broadly delineated connection between historical authorial intentions and the moral interpretation of myths. On the importance of Arnulf's approach see Frank T. Coulson, "New Manuscript Evidence for Sources of the Accessus of Arnoul d'Orléans to the 'Metamorphoses' of Ovid," Manuscripta 30 (1986): 103-7. On the development of the commentary tradition toward a modern concept of authorship see Minnis, Scott, and Wallace, Medieval Literary Theory, esp. 114-16 and 155-58, on Arnulf's commentary on Lucan's De bello civili. For the texts of Arnulf's commentaries and general introductions to his approach see Fausto Ghisalberti, “Arnolfo d'Orléans, un cultore di Ovidio nel secolo XII," Memorie del R. Istituto Lombardo di Scienze e Lettere 24 (1932): 157-234; Arnulfi Aurelianensis Glosule super Lucanum, ed. Berthe M. Marti, Papers and Monographs of the American Academy in Rome 18 (Rome: American Academy in Rome, 1958); and Arnulfi Aurelianensis Glosule Ovidii Fastorum, ed. Jörg Rudolf Rieker, Millennio Medievale 54, Testi 14 (Florence: SISMEL, Edizioni di Galluzzo, 2005).

${ }^{20}$ See Ghisalberti, “Giovanni del Virgilio,” 13-19. Cf. Minnis, Scott, and Wallace, Medieval Literary Theory, 321-23 (360-66 for the English translation).

Speculum 87.3 (July 2012) 
importance for the interpretation of the text's meaning. ${ }^{21}$ Boccaccio follows in this tradition by interpreting the meaning of the gods through the intentionality of the inventors of the myth. In order to understand what they mean, the historical context must be unraveled first. He does not, however, offer a historical context for the poets of classical antiquity, such as Virgil and Ovid; instead he considers the first contemplators of the natural world as poets, and he uses the topos of the poeta theologus to place each myth in a general historical context. His procedure of historicization, however, requires him to go beyond the history of the ancients recorded by eyewitnesses and to employ his own oculus imaginationis, or mind's eye, in re-creating the possible histories of ancient mythic creations. ${ }^{22}$ In doing this Boccaccio imagines every myth in the Genealogie as having been invented by a human being in a determined historical context. If the history of Rome had been the time line according to which Pierre Bersuire and Giovanni del Virgilio could recontextualize the life of Ovid, then, for Boccaccio, Eusebius's Chronicon as translated by St. Jerome was the master text according to which the confused fragments of ancient myth could be placed on a Christian time line. ${ }^{23}$ The aim of the Genealogie, then, as I will present it in this essay, is to overcome the historical distance that separates the contemporary world from the ancient past and to relate the stories of that past within a comprehensible historical context. In order to do so, however, Boccaccio first contextualizes his own position as modern and then self-consciously takes on a primitive point of view.

In the first proem Boccaccio states that his explicit goal is to collect the "membra" " "limbs") of classical myth into "unum genealogie corpus" ("the single body of a genealogy") and to proceed "sensus absconditos sub duro cortice enucleando ... non tamen ad unguem iuxta intentionem fingentium fecisse promictam" ("to explain the meanings hidden under the hard bark ... even though I would not promise to do so perfectly according to the intention of the mythmakers"). ${ }^{24}$ He further demonstrates that finding the intention of the ancients is indeed his purpose in the pathos-filled exclamation that follows: "Quis enim tempestate

\footnotetext{
${ }^{21}$ See Minnis, Scott, and Wallace, Medieval Literary Theory, 65-71 (Hugh of St. Victor and Abelard) and 203-7 and 266-76 (Nicholas of Lyre). See also Alastair Minnis, Medieval Theory of Authorship: Scholastic Literary Attitudes in the Later Middle Ages, 2nd ed. (Aldershot: Scolar, 1988), 91-92 and 152-53.

${ }^{22}$ Thus, for Boccaccio, the link between history and the imagination is much more complex than it was for his predecessors, such as Hugh of St. Victor and Isidore of Seville, who thought that history could only be written by those who had seen the events that they had recounted, lest falsehood be mixed with truth (see PL 175:12 and Etymologiae 1.41.1). In his discussion of fabulae in Book 14 , Boccaccio states that epic poets recount events that "si de facto non fuerint, cum communia sint esse potuere vel possent" ("if they did not actually happen, they could happen or could have happened since they are common events"; 14.9.7). In the Genealogie he similarly recounts what might possibly have happened; and although he cannot always confirm it, since, as he puts it in his exposition of Aesculapius, "hystoria mixta poeticis est" ("history is mixed with fictions"; 5.19.3), he always directs his inquiry toward the verisimilar.

${ }^{23}$ In his edition (871-73) Romano notes that Boccaccio cites Eusebius's Chronicon over a hundred times in the Genealogie. These citations provide the framework for a historical contextualization of pagan poetic invention that parallels the Old Testament histories.

${ }^{24}$ Genealogie 1.proem 1.40-42.
}

Speculum 87.3 (July 2012) 
nostra antiquorum queat terebrare pectora et mentes excutere, in vitam aliam iam diu a mortali segregatas, et, quos habuere, sensus elicere? Esset edepol divinum potius quam humanum!" ("For who in our time could penetrate the hearts of the ancients and examine their minds, segregated in another life by death? Who could elicit the meanings that they held? It is a divine task, not human!"). ${ }^{25}$ Besides the recognition of the difficulty presented by historical distance, this passage shows, in fact, that the motivation behind Boccaccio's work is to understand what ancient peoples felt and thought ("pectora et mentes"). In the phrase that precedes that declaration, Boccaccio compares his labor to that of another Prometheus, who "prisco tempore consueverat homines ex luto componere" ("in the earliest times used to put together men out of mud"). ${ }^{26} \mathrm{He}$ must reconfigure the men of the past out of the muddled fragments of them that he has at his disposal. These fragments, he says, are scattered like the remains of a shipwrecked vessel along the shore, and he will have to travel far and wide in order to gather them into a single body. ${ }^{27}$ Yet this body made by a new Prometheus will be broken and mutilated, like a Hippolytus in need of an Aesculapius. ${ }^{28}$ Time, hatred, envy, and other forces have contributed to the irretrievability of the past. ${ }^{29}$ Boccaccio presents his approach as impossible; it can only succeed inasmuch as the mythographer is capable of reconstructing rhetorically the fragments of the past. Boccaccio is extremely self-conscious of his modernity, yet he is ready to feign a primitive perspective in order to relate the imagination of the past to his own epoch. ${ }^{30}$ So, instead of a scientific method of interpretation, the proems to the Genealogie offer the reader metaphorical representations of Boccaccio's approach to the past.

The meanings he will explain are those of the ancients themselves, insomuch as the author is able to reconstruct them rhetorically, and he will link them in genealogical fashion to those of later poets and commentators, so that the ultimate

\footnotetext{
${ }^{25}$ Genealogie 1.proem 1.42. That Boccaccio might be inserted in a literalist or historicist line of biblical commentators is attested in the lines that follow this quotation. Comparing the multiplicity of diverse opinions and interpretation of ancient texts with those of the Bible, Boccaccio writes: "Nec mirabile; videmus enim divini voluminis verba ab ipsa lucida, certa ac immobili veritate prolata, etiam si aliquando tecta sint tenui figurationis velo, in tot interpretationes distrahi, quot ad illa devenere lectores" ("This is no marvel. For we see that the words of the Bible, brought forward from the same luminous, certain, and immobile truth, even though sometimes they may be housed by the thin veil of allegory, are pulled apart into as many interpretations as there are readers that approach them"; 1.proem 1.43).

${ }^{26}$ Genealogie 1.proem 1.41. On Prometheus as a figure for the mythographer see Lucia Marino, "Prometheus or the Mythographer's Self-Image," Studi sul Boccaccio 12 (1980): 263-73; Tobias Foster Gittes, "St. Boccaccio: The Poet as Pander and Martyr," Studi sul Boccaccio 30 (2002): 125-57; and Susanna Barsella, “The Myth of Prometheus in Boccaccio's 'Decameron,'” in Walter Stephens, ed., Studia humanitatis: Essays in Honor of Salvatore Camporeale = Modern Language Notes 119, suppl. 1 (2004), 121-41. Boccaccio also figures himself as Mercury, Atlas, Daedalus, Hercules, and Aesculapius.

${ }^{27}$ Genealogie 1.proem 1.39-41.

${ }^{28}$ Genealogie 1.proem 1.50-51.

${ }^{29}$ Genealogie 1.proem 1.25-38.

${ }^{30}$ Boccaccio supposedly begins his endeavor at the request of Hugh IV of Cyprus, who desires all the stories of the ancients collected in one volume. Boccaccio says that he is unsuited for the job and proposes Petrarch to the king's emissary, Donnino da Parma, as a scholar capable of creating a pristine body for those stories. See Genealogie 1.proem 1.18-24.
}

Speculum 87.3 (July 2012) 
authority is the human institution of poetry itself. The ancients, Boccaccio writes, had such prudence that, even though they were not Christian, "nil artificiosius humani ingenii fictione velatum sit, nec verborum cultu pulchrius exornatum" ("nothing was more artistically veiled by the invention of the human imagination, and nothing was more beautifully decorated by the cult of words"), and "ex quibus patet liquido eos plurima mundana sapientia imbutos fuisse" ("from this it is clear that they were filled with much wisdom of the world"). ${ }^{31}$ Thus Boccaccio begins his study with the aim of understanding not only the "deorum consanguinitates et affinitates explicitas" ("explicit blood relations and affinities of the gods") but the story of the inventive powers of the human ingenium that myths tell. His priority is to retrace the gods to their human origins, and so it is only fitting that his preferred method of interpretation is historical. It is this same search for origins that leads Boccaccio to choose the genealogical structure, which had never before been used in a work of such a grand scope. ${ }^{32}$ In order for a genealogy to function, however, he must find the original pagan god from whom all others were generated.

Given the basic premises of euhemerism, this means that Boccaccio must retrace the original beliefs of primitive man back to their beginnings in the idolatry of a king. Boccaccio, however, applies the underlying premises of euhemerism to the natural world, explaining the origins of poetry as the result of human marvel before nature, and positing the first poets as prisci theologi, or primitive theologians, who hid natural truths under a poetic veil. ${ }^{33}$ If euhemeristic interpretation has all of the gods as men deified by men, then Boccaccio extrapolates from this that the first gods, before men lived in a civilized society, were natural phenomena that were given body and character by the first primitive humans. Of the gods treated in the first book, only one is reduced to a truly euhemeristic origin, whereas the rest were all created by men's marvel before a nature that they could not comprehend. ${ }^{34}$ By developing the medieval historicist tradition to include naturalistic interpretations, Boccaccio allows all myth to be understood

\footnotetext{
${ }^{31}$ Genealogie 1.proem 1.44-45.

${ }^{32}$ For previous mythical genealogies with which Boccaccio was familiar see sections 1-5 of Hygini fabulae, ed. Peter K. Marshall (Stuttgart: Teubner, 1993); Paolo da Perugia, Le geonologie [sic] degli uomini e degli dei di Paolo da Perugia, in Hortis, Studj, 525-36; and Franceschino degli Albizzi and Forese dei Donati, Genologia [sic] deorum, in Hortis, Studj, 537-42. On Paolo da Perugia see also Teresa Hankey, “Un nuovo codice delle 'Genealogie deorum' di Paolo da Perugia,” Studi sul Boccaccio 18 (1989): 65-162. Boccaccio's models for the Genealogie, as is seen especially in his use of the trees that decorate the beginning of each book, included also the Jesse tree found in medieval manuscripts of the Bible, which traced the lineage of Christ, the genealogies of the Old Testament, Roman patristic stemmata, genealogies of Charlemagne, and the arbor iuris (Wilkins, Trees, 25-27). More generally on the tree as symbol see Michel Pastoureau, L'arbre: Histoire naturelle et symbolique de l'arbre, $d u$ bois et $d u$ fruit au moyen âge, Les Cahiers du Léopard d'Or 2 (Paris: Léopard d'Or, 1993). Surprisingly close to Boccaccio's genealogical approach is a twelfth-century Liber de natura deorum, edited in Virginia Brown, "An Edition of an Anonymous Twelfth-Century 'Liber de natura deorum," Mediaeval Studies 34 (1972): 1-70. On this mythography and its possible relation to Boccaccio, given that both use Theodontius as a source, see Judson B. Allen, "An Anonymous Twelfth-Century 'De natura deorum' in the Bodleian Library,” Traditio 26 (1970): 352-64.

${ }^{33}$ Genealogie 15.8 .

${ }^{34}$ This is the myth of Tages, son of the earth (1.12); it will be treated further below, 753-55.
} 
under the aegis of the human imagination, whether its meaning is ethical or natural. The genealogical trees that develop the lineages of the gods are in this way also a lineage of human poetic creations. Any genealogical approach to the past is directed toward the telos of the present state of things. Just as a genealogical approach has the power to uproot the present by unveiling the lack of an origin, it is also able to ground the present in the stories of the past and to trace the routes of metamorphosis by which the past becomes the present. Boccaccio's history of theology in the Genealogie is a history of humanity's imaginative engagement with the world of creation, both natural and political, according to which the present must seek not merely to imitate the poetic models of the past but to understand the principle of translation by which the past's poetic forms change into those of the present.

At the beginning of the second proem to Book 1 Boccaccio states that he will have found his starting place "dum eum comperero quem sibi primum deum finxere priores, ut, ab eo initio propaginis sumpto, debito possim ordine in posteritatem procedere" ( "once I will have found what god the first men created for themselves so that, taking from him the beginning of the line, I may proceed into posterity with due order"). ${ }^{35}$ Here the word "finxere" is central to how Boccaccio understands the origins of human myth. It means both "to create" and "to create fictions about" and thus links myth as poetry (language) and myth as human creation (history). By finding a beginning in human fiction he may move toward the posterity of human fiction. ${ }^{36}$ The process by which Boccaccio chooses this first god is tantamount to understanding the anthropological perspective that his historicist approach brings to the exposition of myth.

Trying to find the origin of the lineage of the ancient gods, Boccaccio describes his contemplation as such:

Conveneram igitur mecum omnes animi vires et e sublimi mentis speculo omnem fere orbis intuebar ambitum, surgentesque extemplo plurimos vidi nec unius tantum religionis homines cuiuscunque tamen veritatis fidedignissimos testes, gravitate asserentes sua deum unicum esse.

I had therefore called to myself all the powers of my mind, and from the sublime lens of my mind I looked upon almost the entire sphere of the world, and I saw immediately many men rise-men not only of one religion-who were nonetheless the most trustworthy witnesses of every truth, men who affirm with their gravitas that there is a single god. ${ }^{37}$

In his mind's eye- “e sublimi mentis speculo"-Boccaccio sees many men of many different religions, who were "veritatis fidedignissimos testes" ("the most

\footnotetext{
${ }^{35}$ Genealogie 1.proem 2.1.

${ }^{36}$ Although "posteritatem" here has been understood as referring to the later generations of gods, the lack of an adjectival qualifier or a substantive in the genitive, which would clarify what posterity (human or divine), allows the reader to understand it as both the continuation of the divine lineages and the human poetic posterity that underlies all of Boccaccio's later analyses. Zaccaria translates this phrase as "quando avrò trovato qual dio per primo gli uomini più antichi si crearono, per poter procedere con ordine verso i successivi dei, dopo aver preso da lui l'inizio della stirpe” (7:65). See also Hyde, "Boccaccio."

${ }^{37}$ Genealogie 1.proem 2.2.
}

Speculum 87.3 (July 2012) 
trustworthy witnesses of the truth") and who believed that there was a single god at the beginning of things, a prime mover in the Aristotelian sense. Still from the distance of his mind's eye, he begins "mente revolvere veterum quam plurium circa hunc varias atque diversas opioniones" ("to unroll with my mind the various and different opinions of many ancients about this god")..$^{38}$ Finally, he criticizes these ancients (veteres) for giving the first god the attributes of the Creator, an error caused by philosophers and poets who "ostenderent prisce ruditati" ("demonstrated [it] to the earliest primitive [humanity]"). ${ }^{39}$ Already here, even before Boccaccio considers the "phylosophantes ... diversimode sentientes" ("philosophers ... of different thought"), there is a dilation of historical time between the beliefs of the priores and the opinions of the veteres. ${ }^{40}$ Boccaccio's job as a scholar of primitive belief is to consult the veteres, who have interpreted the beginning of pagan belief, in order to glean what it must have meant for the first pagans, the priores. The meanings attributed by the ancient philosophers depend on the original, unsophisticated belief of the first humans.

With the diverse opinions of philosophers and poets, the original single god was made monstrous, and from him "plures et diversos deos" "'many different gods") were held to be true by the diverse "nationes vel secte" ("nations or sects"), each of which considered its own god to be the "verum et primum et unicum ... deum aliorum patrem et dominum" ("the true, first, and only ... god, father, and lord of the others"). ${ }^{41}$ The result was worse than the three-headed Cerberus: "Et sic non solum ad instar Cerberi tricipitem fecere beluam, quin imo in monstrum longe plurium capitum describere conati sunt" ("And so they made not only a three-headed beast, but rather they tried to describe him as a monster of far more heads"). ${ }^{42}$ Wanting to behead this monster and leave him with his original face, Boccaccio first consults Thales, the most ancient of the philosophers ("quorum ... antiquissimum"), who was "suo evo sapientissimum hominem et celo astrisque familiarissimum" ("in his own age an extremely wise man who was extremely learned about the heavens and the stars").43 He asks Thales to tell him who was the first of the gods, and the ancient cosmographer responds eagerly: "Rerum omnium causam primam aquam fuisse reor, eamque in se divinam habere mentem, omnia producentem" ("I think that the first cause of all things was the water and that the water had a divine mind in it, producing all things"). ${ }^{44}$ Boccaccio immediately moves on to the next most ancient, Anaximenes, who responds to the same question that the air $(a e r)$ produced all things. Boccaccio goes on to consult Chrysippus, "inter priscos famosus homo" ("a famous man among the ancients"), who holds fire (ignis) to be the creator of all things, then Alcmeon, "ceteris celsioris animi hominem" ("a man of higher

\footnotetext{
${ }^{38}$ Genealogie 1.proem 2.3.

${ }^{39}$ Genealogie 1.proem 2.4.

${ }^{40}$ Ibid.

${ }^{41}$ Ibid.

${ }^{42}$ Genealogie 1.proem 2.5.

${ }^{43}$ Ibid.

${ }^{44}$ Genealogie 1.proem 2.6.
} 
mind than the others"), who sides with the entire heavens (omne celum). ${ }^{45}$ The description of Alcmeon is indicative of how Boccaccio conceives of the opinions of ancient philosophers:

Nam elementis transvolatis repente intellectu se miscuit astris, inter que, que noverit nescio, sed retulit se arbitrari solem, lunam et stellas et omne celum rerum omnium fuisse fabros. O liberalis homo! Quam uni tantum elemento ceteri dederant, hic omnibus supercelestium corporibus deitatem largitus est.

For, having flown beyond the elements, immediately with his intellect he mixed himself with the stars, among which I know not what he found out, but he reported that he thought that the sun, the moon, and the stars and the entire heavens were the makers of all things. Oh, what a generous man! That divinity the others had attributed only to a single element, he distributed to all the bodies of that which rests above in the heavens. ${ }^{46}$

Each philosopher is more learned than the other, but each is also further removed from the terrestrial arena. Thales explained why he thought water to be the first cause by comparing the creative power of water to a human act: "omnia producentem nec aliter quam apud nos plantas humectet" ("producing all things just like we do when we water plants”). ${ }^{47}$ But by the time Boccaccio reaches Alcmeon, there is no reference whatsoever to earthly concerns. The ancient philosopher is flying over the elements, and his intellect is intermixed with the stars. Boccaccio doubts ("nescio") what he could have discovered there. The more rarefied the explanations get, the more unsatisfactory they become. In fact, Boccaccio's concluding exclamation about Alcmeon's liberality is entirely ironic. Having extracted himself from the earthly world, Alcmeon shows his largesse ("largitus") by attributing the act of creation to not one but three heavenly bodies. The itinerary traced thus far in Boccaccio's interrogation of ancient authorities must be taken as a biting critique of previous mythographers who had sought to find natural truths in myth by recourse to allegory alone; such interpreters were followers of Varro's physical theology loved by the Stoics and deprecated by Cicero's Cotta in De natura deorum and by Augustine in De civitate Dei. ${ }^{48}$

The only ancient consulted in this imaginary interview whose texts Boccaccio actually knew is Macrobius, who is described as "iuniorem omnium" ("the youngest of them all"). Of his opinion Boccaccio says only that he attributed "solo soli ... quod dederat Alcinous toti celo" ("to the sun alone ... what Alcmeon had given to the entire heavens").49 Here Macrobius functions as a foil to Alcmeon in that his generosity (compatible with and proleptic of Christianity) is limited to the one while the ancient Greek gives divinity to the whole heavens. Macrobius

\footnotetext{
${ }^{45}$ Genealogie 1.proem 2.8-9.

${ }^{46}$ Genealogie 1.proem 2.9.

${ }^{47}$ Genealogie 1.proem 2.6.

${ }^{48}$ Although he never openly mentions them, Boccaccio's critique, in my view, is clearly of the disembodied philosophical interpretations of myth from the so-called school of Chartres, such as Bernardus Silvestris's De mundi universitate and Pseudo-Silvestris's commentary on Martianus Capella's De nuptiis Philologiae et Mercurii.

${ }^{49}$ Genealogie 1.proem 2.10. As Zaccaria notes, “Alcinous is an error for Alcmaeo" (8:1613 n. 22).
} 
is the bridge between ancient and modern in this list of authorities, and his importance for medieval exegesis of pagan poetry was indeed unmatched..$^{50}$ Finally, Boccaccio consults the modern Theodontius, a "novus homo" and an "investigator precipuus" ("new man" and "important investigator"), who answers the same question as the others from a different point of view, without citing any authority ("neminem nominando"): "vetustissimorum Arcadum fuisse opinionem terram rerum omnium esse causam, eique, ut de aqua dicit Thales, mentem inesse divinam existimantes, crediderunt eius opere omnia fuisse producta atque creata" " it was the opinion of the most ancient Arcadians that the earth was the cause of all things and that, as Thales said about the water, there was a divine mind in it, and they believed that all things had been produced and created by its work")..$^{51}$ Earlier Thales responded to Boccaccio's question by saying what he thought ("reor"), Anaximenes with an assured statement of truth ("aerem rerum omnium productorem [esse]"), Chrysippus with his own belief ("se credere"), and Alcmeon with a report from on high of what he thought ("se arbitrari"). Their authority is based on the gravitas, or intellectual weight, of their thought, as Boccaccio mentioned in the incipit to the interview: "gravitate asserentes sua" ("asserting according to their intellectual weight").52 Yet by the time Boccaccio reaches Alcmeon, this gravitas has become ironically and ridiculously light and has departed from the terrestrial origins of human thought. ${ }^{53}$ Theodontius's opinion, however, is based on the "vetustissimorum Arcadum ...

\footnotetext{
${ }^{50}$ Although there is little hard evidence for or against Macrobius's Christianity, he is generally not considered Christian. On the issue of Macrobius's religiosity see Alan Cameron, "The Date and Identity of Macrobius," Journal of Roman Studies 56 (1966): 25-38, where he argues that Macrobius was not a Christian but that his Neoplatonic doctrines were not out of line with Christian doctrine. This is also evident from the ease with which Macrobius was translated into twelfth-century mythopoetic thought. For the opposite view see William Harris Stahl's introduction, in Macrobius, Commentary on the Dream of Scipio, Records of Civilization: Sources and Studies 48 (New York: Columbia University Press, 1952), 6-9. See also Jacques Flamant, Macrobe et le néo-platonisme latin à la fin du IVe siècle, Études Préliminaires aux Religions Orientales dans l'Empire Romain 58 (Leiden: Brill, 1977).

${ }^{51}$ Genealogie 1.proem 2.10. On the mysterious Theodontius, whose lost work on myth Boccaccio often cites according to what he knows of it from Paolo da Perugia, see Pastore Stocchi, "Da Crisippo al Boccaccio," where he argues for a greater appreciation of Theodontius's reliability as a source of Greek knowledge. See also the information reported in Hortis, Studj, 464-68.

${ }_{52}$ Genealogie 1.proem 2.2.

${ }^{53}$ The term gravitas was synonymous-or in a synecdochical relationship-with auctoritas in Boccaccio's sources. Pliny the Younger uses the term as a synonym for sanctitas and auctoritas in book 2 of his letters: "Praeterea Cottius ipse tam clarum specimen indolis dederat, ut vita eius brevis et angusta debuerit hac velut immortalitate proferri. Nam tanta ei sanctitas gravitas auctoritas etiam, ut posset senes illos provocare virtute, quibus nunc honore adaequatus est" (13.4); Epistularum libri duo, ed. James Cowan (Hildesheim: Olms, 1983). On the term gravitas and its relation to auctoritas in the Roman world see Karl Galinsky, Augustan Culture: An Interpretative Introduction (Princeton: Princeton University Press, 1996), 166; on the term and its relation to authority (auctoritas) and dignity (dignitas) see Jean-Philippe Lévy, "Dignitas, gravitas, auctoritas testium," in Studi in onore di Biondo Biondi, 4 vols. (Milan: Giuffrè, 1965), 2:27-94; on these terms in the Middle Ages see Jacques Le Goff, History and Memory, trans. Steven Rendall and Elizabeth Claman (New York: Columbia University Press, 1992), 12, where he sweepingly declares, “The term 'antiquity' (antiquitas) is synonymous with authority (auctoritas), value (gravitas) and majesty (majestas)."
} 
opinionem" ("opinion ... of the most ancient Arcadians"). He looks beyond any advanced scientific meaning of the myth to imagine what primitive humanity itself must have believed. He cites no one because his authority is a pretextual, anthropological authority that for Boccaccio trumps the ancient philosophers. To call this authority "anthropological" is to highlight the centrality of the human, anthropeios, as opposed to the philosophical or theological authority of other fourteenth-century mythographers, such as Pierre Bersuire and Giovanni del Virgilio. Throughout the Genealogie Boccaccio seeks to trace the original meaning of myths in history to their possible meanings in a Christian worldview, but he does this by analyzing their value-whether natural or ethical—on a human plane, without directly referencing the Christian theological tradition. ${ }^{54}$

Boccaccio's modernity, following that of Theodontius, is defined by the way in which he looks back at antiquity. No longer tied to a single literary text as mythographers of the medieval commentary tradition were, Boccaccio is able to imagine retrospectively the religious beliefs of antiquity as a cultural production that was older than poetic authorities, such as Virgil or Ovid. At the same time he also detaches his critical perspective from the philosophical ideologies of Stoicism and Neoplatonism in the allegorizations of Macrobius, Claudian, Martianus Capella, and others that helped found Christian mythography. ${ }^{55}$ In the most modern of approaches he finds the most ancient authority. Theodontius cannot name anyone as an authority because no written authority exists for the opinions of the vetustissimi. Boccaccio's point of view represents a new approach that relies both on reason and on imagination, an approach that seeks to reconfigure the human history hidden behind the veil of poetry and to trace that history to the philosophical meanings of myth in Greco-Roman poetry and the theological meanings of myth in Christian commentary and poetry. Through a simple use of the superlative-vetustissimi instead of vetustes-Boccaccio differentiates between the intention of those primitives who first created ancient myths and the ancient poets who continued the mythic tradition in later antiquity. He establishes the dilation of time demanded by a genealogical structure and reveals the human foundations of his divine genealogy.

The human point of view represented by Theodontius's opinion is the foundation upon which Boccaccio's analyses are constructed. Having deduced that the most primitive ancients held the creative powers of the earth- "terram rerum omnium productricem" ("the earth, producer of all things"), or Natura naturans-as the first of the gods, which Theodontius recorded as being called Demogorgon,

\footnotetext{
${ }^{54}$ By using the term "anthropological" I do not mean to suggest that Boccaccio was the founder of the modern science of anthropology or archaeology. Nevertheless there are many points of convergence between Boccaccio's method and modern scientific approaches to humanity and the past, just as there are with Livy and Herodotus. On the prospects of tracing the origins of the modern anthropological sciences to medieval humanism see Margaret Trabue Hogden, Early Anthropology in the Sixteenth and Seventeenth Centuries (Philadelphia: University of Pennsylvania Press, 1964), 15-108. On Boccaccio's "anthropological" and "archaeological" tendencies in representing antiquity in the Teseida see Jeffrey T. Schnapp, "A Commentary on Commentary in Boccaccio," South Atlantic Quarterly 91 (1992): 813-34.

${ }^{55} \mathrm{On}$ the role that these commentators played in medieval and early modern mythography and in the exegesis of classical texts see Chance, Medieval Mythography, 1.
}

Speculum 87.3 (July 2012) 
Boccaccio goes on to describe the historical poetic process that led to the divine naming. The most ancient humans, he writes, were "mediterranei ... homines atque montani et semisilvestres" ("men of the earth, ... mountain men and half savages"), who saw

terram sponte sua, silvas et arbusta queque producere, flores, fructus et semina emictere, animalia alere cuncta et demum in se morientia queque suscipere, nec non et montes flammas evomere, ex duris silicibus ignes excuti, ex concavis locis et vallibus exalare ventos et illam sentirent moveri non nunquam et etiam mugitus emictere eiusque ex visceribus fontes, lacus et flumina fundi, quasi ex ea ethereus ignis et lucidus aer exorti ac egregie potata ingentem illum occeani pelagum eminxerit, et ex collisis incendiis evolantes in altum favillule solis luneque globos ediderint, summoque implicite celo in stellas sese infixerint.

the earth spontaneously produce the forests and all the shrubs, and send forth the flowers, fruits, and seeds, nourish all the animals and house them in itself when they died, and the mountains spew out flames, and fire be sent forth from hard rocks, and wind blow out of caves and valleys; and they felt the earth move sometimes and even let out groans and from its bowels founts, lakes, and rivers flowed, as if the ethereal fire and clear air had been born from it and, having taken a big drink, it had let out that huge sea of the ocean, and sparks from the colliding fires, flying high up, had created the spheres of the sun and moon and, scattered in the deep heavens, had become fixed into stars. ${ }^{56}$

Here the hyperbolic nature of the list of what primitive humans saw communicates their awe before what seemed to sprout of its own will. Conjunctions, such as "nec non et" and "non nunquam et etiam," convey an untranslatable excitement on the part of Boccaccio, who seems to identify directly with the primitives' vision of the earth. Boccaccio's rhetorical representation of the creative powers of the earth is meant to mimic what the primitive human race must have seen. The description of the primitive materiality of the earth clearly recalls the byle of Plato's Timaeus as it is interpreted by Bernardus Silvestris in the De mundi universitate. Boccaccio reads the chaotic beginnings of the world, however, through the minds of those silvestri whom Silvestris believed inhabited the primitive world..$^{57}$

Those who followed these ancient inhabitants of the fields, Boccaccio continues, were "paulo altius sentientes" ("a little more intelligent"); they not only believed the earth to be the "rerum harum ... autorem" ("the author ... of these things") but said that it had a "mentem ... divinam" ("divine ... mind") within

\footnotetext{
${ }^{56}$ Genealogie 1.proem 3.3.

${ }^{57}$ In the commentary to the De mundi universitate Bernardus Silvestris notes: "Nam quis facile mundum semper fuisse consentiat, cum ipsa historiarum fides multarum rerum cultum emendationemque vel ipsam inventionem recentem esse fateatur, cumque rudes primum homines et incuria silvestri non multum a ferarum asperitate dissimiles meminerit vel fabuletur antiquitas ..." ("For who would readily agree that the world has always existed when the testimony of historical accounts implies that the development, improvement, and even invention of many crafts is of recent date, when the ancients recall or relate in legends that, in the beginning, men were uncultivated and, in their rustic crudeness, not unlike wild beasts ..."); Bernardi Silvestris De mundi universitate libri duo sive Megacosmus et microcosmus, ed. C.S. Barach and J. Wrobel (Innsbruck: Wagner, 1876); trans. Stock, Myth and Science, 81. On the initial myth of the Genealogie as a representation of byle see Mazzotta, "Boccaccio," 358-59.
} 
it. ${ }^{58}$ The primitive poetic imagination attributed this divine mind to Demogorgon, since the rustics of Arcadia believed him to dwell "in terre visceribus" "in the bowels of the earth"). .9 This belief grew when the priores began to enter the caves of the earth, "cum in processu languescente luce silentium augeri videatur, subintrare mentes cum nativo locorum horrore religio consuevit et ignaris presentie alicuius divinitatis suspicio quam a talibus suspicatam divinitatem" ("since, later, with the languishing light, silence seems to grow, along with the natural horror of the places, religion secretly began to enter their minds and, since they did not know, the suspicion of the presence of some divinity"). ${ }^{60}$ The initial marvel felt by these ancient farmers, in combination with the mysterious horror of the earth's viscera, led them to create the first god and the first sense of religion in the first human fictio about nature. It is the very excess of the primitive experience of nature that causes the first poets to give it a name, so that they might contain and control their overwhelming sense of marvel. By naming the source of creation, Boccaccio's primitives become alienated from nature. The selfawareness signaled by their marvel renders the creative power of nature an absolute and uncontainable other. The poetic creation of the figure of Demogorgon mirrors the expulsion of Adam and Eve from the garden of Eden into the mutable realm of history and language. Although this god is the result of a medieval misreading, it was not created ex novo by Boccaccio. ${ }^{61}$ It is rather an original fiction that leads to other fictions, all of which evidence the centrality of poetic language and the imagination in human endeavors to understand (and re-create) the world that surrounds them. All poetic imagination, then, even in the post-Incarnation world of Boccaccio, is related to this original fictio, which veils truths about the human relationship with the natural world. Boccaccio's method is one of historical deduction that unveils the original psychological and sociological motivating factors behind the creation of a myth and de-allegorizes that myth so that he can trace a historical lineage of allegoresis. He transfers

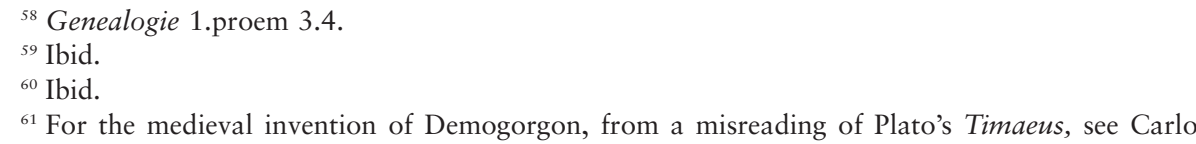
Landi, Demogòrgone: Con saggio di una nuova edizione delle "Genealogie deorum gentilium" del Boccaccio e silloge dei frammenti di Teodonzio (Palermo: Sandron, 1930); and Maurice Castelain, "Demogorgon ou le barbarisme déifié," Association G. Budé Bulletin 26 (1932): 22-39. See also Hyde, "Boccaccio," who asserts that Demogorgon was purposefully and ironically invented by Boccaccio. Don Cameron Allen, following Lilio Gregorio Giraldi, finds the misreading as having originated in Lactantius's commentary on Statius's Thebaid 4.516 (Mysteriously Meant, 216). David Quint finds that Arnulf of Orléans's commentary on Lucan's De bello civili was a more likely source for Boccaccio: "Epic Tradition and Inferno," Dante Studies 93 (1975): 201-7. The only other mythographers to assert that Demogorgon was the first god were Paolo da Perugia and the anonymous twelfthcentury author of a De natura deorum (in Brown, "Edition"), both of whom presumably used Theodontius as a source. Paolo da Perugia, who prefers Chaos to Demogorgon as the first god, mentions Demogorgon nonetheless: “Aliquorum opinio fuit quod Demogorgon fuit primus": Hankey, "Un nuovo codice," 91. On Theodontius as the common source for these genealogies see Allen, "An Anonymous Twelfth-Century De natura deorum," and Hankey, "Un nuovo codice." Hankey also notices that Demogorgon figures in Conrad de Mure's 1273 poem Fabularius, his earlier Novus Graecismus, and Paolinus Minorita's mid-fourteenth-century Chronologia magna: "Un nuovo codice, $" 71-85$.

Speculum 87.3 (July 2012) 
the human, historically contingent origins of myth intrinsic in euhemerism onto the natural interpretations that were once opposed to or at best irrelevant to the historical method. The poetic imagination in combination with a natural wonder and horror gave rise to the sacral naming in which the institution of poetry and civilization itself originate. Poetry's beginning is simultaneous with the beginning of history - both flow out of nature. The first book of the Genealogie, which follows directly after the description of Demogorgon, traces the diverse figurations of the creative powers of the earth across a human temporal continuum. This is to say that Boccaccio interprets the philosophical concepts relative to nature (matter, time, creation, sustenance, etc.) from an anthropological perspective.

In order to understand how Boccaccio saw the relationship between history and nature in the imagination of the ancients, it is necessary to examine Demogorgon's coeternal companions: Chaos and Eternity. In his explication of Eternity, Boccaccio writes that the ancients thought that nature was eternal and that Eternity represented this pure, infinite time: "Que quid sit suo se ipsa pandit nomine, nulla enim temporis quantitate mensurari potest, nullo temporis spatio designari, cum omne contineat evum et contineatur a nullo" ("She manifests what she is by her very name: she cannot be measured by any quantity of time, cannot be designated by any space of time, since she contains all time and is contained by nothing"). ${ }^{62}$ In an analysis of a passage from the De consulatu Stiliconis by Claudian, ${ }^{63}$ Boccaccio asserts that the most ancient Arcadians believed that Eternity inhabited a cave in the earth from which she controlled the ages of man: "eamque ... tempora suppeditantem atque revocantem, ut appareat intra eam omne tempus initium sumpsisse ac sumere et sumpturumesse, et ultimo in finem devenire suum" ("and she ... supplies and calls back times in order that it might become apparent that all time has begun, begins, and will begin within it, and finally will come to its end"). ${ }^{64}$ She was also thought to control the order in which times appear: "eumque [serpentem] ... revoluto in caudam ore eam devorantem, ut ex hoc actu percipiamus temporis circularem lapsum" ("the serpent, ... with its mouth turned toward its tail, devours it, so that from this act we perceive the circular passage of time"). ${ }^{65}$ For the ancients, time was circular, ever repeating itself, because they understood it, Boccaccio thinks, from the natural progression of the seasons. He appears to confirm this idea of time when he describes its natural progression: how the end of a year is the beginning of the next, how the year depends on the recurrence of the rotation of the sun, the month on that of the moon, and the day on that of the eighth heaven. ${ }^{66}$ Boccaccio's conception of the way in which

\footnotetext{
${ }^{62}$ Genealogie 1.1.1. Here Boccaccio shows once again how the naming of the divinity both encloses and opens up meaning. The verb "pandit," from pandere, literally means "spreads out, extends; unfolds, expands' and is a synonym of explicat, 'explicates'.

${ }^{63}$ Although Boccaccio arrives at this primitive moment by means of a poem by Claudian (fifth century C.E.), he reads the poem anthropologically as an artifact that points to an era before its composition. In fact, the first thirteen books are not so much commentaries on the poetry of Virgil, Ovid, Statius, et al., as extrapolations of a preliterate poetic thought from the texts of those poets.

${ }^{64}$ Genealogie 1.1.4.

${ }^{65}$ Ibid.

${ }^{66}$ Ibid.
}

Speculum 87.3 (July 2012) 
time is perceived, then, escapes the typical linearity of Christian time, which would reach its end with the Apocalypse. ${ }^{67}$ Ancient time, for him, is both circular and forward moving, since its progression is experienced as a series of revolutions or returns. Boccaccio addresses the problem of nature's relation to history by analyzing the figure of Natura in the passage by Claudian. Natura, he reads, is the guardian of the cave of Eternity because "quod quicquid intrat Eternitatis gremium ... natura rerum agente, intrat, et sic quasi ianitrix hic est, et est intelligendum de natura naturata. Nam quod Natura naturans immictit nunquam egreditur" ("whatever enters the bosom of Eternity ... enters by the agency of the nature of things, and thus she is like a doorkeeper here, and we must understand this as a quality of Natura naturata [born nature]. In fact, that which Natura naturans [creative Nature] lets in can never leave"). ${ }^{68} \mathrm{He}$ interprets the figure of Natura in the poem as signifying Natura naturata, or nature as seen in its effectsphysis. Yet Natura naturans - the higher-order nature that engenders things into time and that the ancients saw in the productive powers of the earth embodied by Demogorgon-does not exist in time but is the agent by which all life enters into time. ${ }^{69}$

Alongside Eternity, Boccaccio finds Chaos, or "quedam omnium rerum creandarum immixta et confusa materia" ("a certain mixed and confused material of all the things that were to be created"), as the second companion of Demogorgon. ${ }^{70}$ This material chaos, "forma certa carentem" ("lacking a definite form"), was believed to be the coeternal companion of Demogorgon since material was needed

\footnotetext{
${ }^{67}$ According to Jean-Claude Schmitt the medieval Christian "representation of historical time" is "both linear (from the Creation to the end of the world) and cyclical": "Appropriating the Future," in J.A. Burrow and Ian P. Wei, eds., Medieval Futures: Attitudes to the Future in the Middle Ages (Woodbridge: Boydell, 2000), 3-18, at 6. The cyclical time that he talks about is the time of liturgy, which saw the return of the same rituals each year. Cyclical time also manifested itself in medieval economic life with rituals, such as "the annual payment of a rent" (ibid., 7). By viewing human history through myth and ritual, Boccaccio sees that the human imagination generates similar versions of gods across time, accumulating meaning in time. It is not the eternal return of Stoic philosophy, nor a simple paradigm repetition whereby the future imitates the past. In the Genealogie historical time progresses forward toward the eschaton, but it is a spiraling trajectory of progress in which the future is a new generation of the past that bears the marks of antiquity on it.

${ }^{68}$ Genealogie 1.1.5.

${ }^{69}$ This philosophical distinction between Natura naturans and Natura naturata is in effect the distinction that Gregory Stone notices in Boccaccio's fiction between Natura and physis, or between nature and the effects of nature (natura rerum). My interpretation of Boccaccio's understanding of the historicity of natura rerum is compatible with Stone's statement that "Boccaccio was, perhaps above all else, concerned to show the historicity of natura and the role of poiesis in the making and unmaking of reality" (Ethics of Nature, 35). Stone argues that Boccaccio understood that physis originated in poetry and history. Thus, "the realm of physis, the physical (material) universe, is one division of nature. But this realm does not extend to the entirety of nature, for there is another division, ethos," which Stone defines as "the attitudes and practices of humans toward other humans and other things, the values that guide humans in their comportment toward the universe" (ibid., 15). The location of Demogorgon within the proems of the first book indicates that the god exists beyond the genealogical time line traced by the treatise. One of Boccaccio's major innovations in the Genealogie consists in the notion that this philosophical order is reflected in the development of human perception, which is recorded in the myths about nature across the time line of the treatise.

${ }^{70}$ Genealogie 1.2.1.
}

Speculum 87.3 (July 2012) 
to "creaturas producere" ("produce creatures"). ${ }^{71}$ The primitive poets who first named Demogorgon gave him as companions both Eternity and Chaos, figures for directionless time and formless material. Their myths record the combination of time and material that generates the material world, physis or Natura naturata. In these initial chapters of the Genealogie Boccaccio describes how the poetic imagination represented this division in nature by becoming conscious of the effects of nature in time. The early myths function as reminders of the first moments of awareness about nature. By naming and making sacred what they saw take place in the world, the first poets gave form to time and material and constructed a manner of thinking about the world. Myth is presented as a hermetic disclosure; it veils the hidden history of the human imagination, and it opens up truths about the nature of the world. The remaining gods of the first book are the children and grandchildren of Demogorgon, that original fiction about Natura naturans. ${ }^{72}$ Each of the gods is descended genealogically from Natura naturans through the poetic imagination, so that in the progression of generations there is not so much a rebirth of the original as a continual effect of transition and translation by which the new participates genetically in the old. Boccaccio reconstructs anthropologically the philosophical order of nature as it came to be recorded in the poetry of the ancients.

In the expositions of the first three children of Demogorgon, Natura naturans becomes Natura naturata in the minds of the ancients. The first son is Litigium, or Discord, whose birth from Chaos Boccaccio interprets as the removal of discordant elements in the creation of order: "Et cum primus dei videretur actus a discordantibus ordinando subtraxisse Litigium, Demogorgonis primus filius dictus est" " And since it seemed that the first act of the god was to remove Discord from the discordant elements by creating order, he is said to be the first son of Demogorgon")..$^{73}$ The poetic fiction of Discord's birth encapsulates a moment when the awareness of nature transitioned into an awareness of the rules that govern nature's effects. Boccaccio reports that the ancients believed Discord had been expelled from the world when Pan and the Parcae (or Fates) were born. The entrance of these gods into the early pantheon denotes a historical transition that takes place in the imagination, from nature's productive energy to its effects:

Eductum autem Pana post Litigium, credo ratos veteres ea in separatione elementorum Naturam naturatam habuisse initium et evestigio domui, id est orbi, Demogorgonis prepositam, quasi eius opere, sic volente deo, omnia producantur mortalia. Parcas autem eodem partu productas et pedissequas fratri datas ideo fictum existimo, ut intelligatur naturam his cum legibus productam ut procreet seu gignat, nutriat et in finem nata deducat.

As for the fact that, after Discord, Pan was born, I believe that the ancients thought that Natura naturata began in that separation of the elements and that she was immediately placed in front of the house of Demogorgon-that is, the earth-as if all mortal

\footnotetext{
${ }^{71}$ Genealogie 1.2.2.

${ }^{72}$ Boccaccio treats Litigium, Pan, Clotho, Lachesis, Atropos, Pollux, Phyton, Terra, and Herebus and their offspring in the first book, leaving out only Ether, son of Herebus and Noctis, daughter of Terra, who is the progenitor at the head of the second genealogical tree.

${ }^{73}$ Genealogie 1.3.11.
} 
things were produced by her work according to the will of the god. As for the fact that the Parcae were produced in the same birth and given as servants to their brother, I believe that it was made up so that one may understand that nature was produced with these laws: to procreate or give birth, to nurture, and to lead things from birth to death. ${ }^{74}$

Pan comes to take over the house of Demogorgon since the imagination turns away from the generative powers of nature and toward the things that make up nature. Boccaccio interprets Pan's birth from Demogorgon and Chaos as a poetic fiction that veils a historical transition from the marvel induced by nature to the contemplation of the effects of nature in the world and the awareness of a natural order. The Parcae were invented as Pan's sisters and servants because the effects of nature in time seemed to the ancients to be governed by laws of procreation, nutrition, and death. For Boccaccio, this poetic invention is contemporaneous with the cultural turn from marvel to contemplation about nature.

Despite the incorrectness of Boccaccio's presentation of the cosmogonic myths of antiquity, he follows a distinct pattern that ties together developments in the human perception of nature and its effects. He reads the myths of nature as if from the point of view of those who created them, yet in a manner that is clearly indebted to medieval thought on nature. ${ }^{75}$ Boccaccio's novelty lies not in the sources or factual knowledge that he adds to the tradition of medieval mythography but in his general approach to mythmaking. He uses the historicism associated with euhemeristic interpretation in order to contextualize the intentions of primitive poet-theologians, making possible a historical approach to myths about the nature of the world. In the proems and initial chapters of the Genealogie Boccaccio offers no notion of his theory of interpretation. Only in the chapter on Discord does he pause to disclose the theory of allegory that will dominate the rest of the treatise. In order to understand more fully how radically Boccaccio adapts euhemeristic historicism to his system of interpretation, I would like to follow him in his digression on allegory.

One of the key reasons why Boccaccio's method has not been properly identified by readers lies in the fact that he never openly exposes it. Like the Decameron before it, the Genealogie is a text that teaches its readers how it works through the process of reading. ${ }^{76}$ If Boccaccio showed in narration that he would take a human perspective on myth, then his theory of allegory is equally embedded in the narrative he is telling about the ancients' representation of nature. Although he offered allegorical readings of Demogorgon, Eternity, and Chaos in the expositions quoted above, he did not explain clearly his understanding of allegory in

\footnotetext{
${ }^{74}$ Genealogie 1.3.14.

${ }^{75}$ For example, the initial description of the first god of the earth is quite similar to Bernardus Silvestris's representation of the creation of the world in the first part of the De mundi universitate. On Bernardus Silvestris's understanding of primal material see Stock, Myth and Science, 97-118.

${ }^{76} \mathrm{On}$ the Decameron as a meditation on the act of reading and interpreting, and as a text that teaches its readers to interpret the world, see Millicent Joy Marcus, An Allegory of Form: Literary Self-Consciousness in the "Decameron," Stanford French and Italian Studies 18 (Saratoga, CA: Anma Libri, 1979); Giuseppe Mazzotta, The World at Play in Boccaccio's "Decameron" (Princeton: Princeton University Press, 1986); and Teodolinda Barolini, "'Le parole son femmine e i fatti sono maschi': Toward a Sexual Poetics of the 'Decameron' (Decameron II 10)," Studi sul Boccaccio 21 (1993): 175-97.
}

Speculum 87.3 (July 2012) 
the proems, as his contemporary Pierre Bersuire did in the preface to his Ovidian commentary.7 Only with the exposition of Discord does Boccaccio pause to teach his patron how to read allegorically. The theory he quickly develops through a reading of the myth of Perseus and the Gorgon imitates the story about nature that he has just told.

About halfway through the chapter on Discord Boccaccio asks his patron, King Hugh IV, if he has understood the story: "Habes, rex inclite, ridiculam fabulam?" ("Do you understand, glorious king, the ridiculous tale?"). ${ }^{78}$ In explaining to the king how to interpret, he intends to respond to those who question why poets treat the works of God, nature, and men beneath the veil of myths. On behalf of the poetic vocation, he cites Macrobius from the commentary on the dream of Scipio, where the Neoplatonist writes that it is against nature to expose her secrets and that poetry follows nature's own process of self-masking by treating the secrets of nature in veiled discourse. ${ }^{79}$ Boccaccio goes on to explain further that these myths have multiple meanings:

Insuper, rex precipue, sciendum est his fictionibus non esse tantum unicum intellectum, quin imo dici potest potius polise[m]um, hoc est multiplicium sensum. Nam sensus primus habetur per corticem, et hic licteralis vocatus est: alii per significata per corticem, et hi allegorici nuncupantur.

Moreover, noble king, one must know within these fictions there is not only a single understanding, but it can be said that they are polysemous, that is, of multiple meanings. In fact the first sense is held through the cortex, and it is called literal; the others are held through what is meant by the cortex, and these are called allegorical. ${ }^{80}$

In this passage Boccaccio describes the expository and interpretative practice of veiled discourse, or integumentum, but he quietly shifts the boundaries between poetic and theological allegory, making the literal, or historical, sense central to the other allegorical meanings. ${ }^{81}$ Myths, then, do not have an ultimate meaning

${ }^{77}$ On Bersuire's theory of allegorical interpretation see Reductorium morale, liber XV: Ovidius moralizatus, ed. J. Engels (Utrecht: Rijksuniversiteit, Instituut voor Laat Latijn, 1962), 1-5. See also Minnis, Scott, and Wallace, Medieval Literary Theory, 317-18. For Bersuire, the interpretation of the gods as astrological phenomena was the literal meaning; he declares early on that he will not treat it.

${ }^{78}$ Genealogie 1.3.5.

${ }^{79}$ Genealogie 1.3.6. See Macrobius, Commentarium in Ciceronis somnium Scipionis, in Opera, vol, 1, ed. Ludwig von Jan (Leipzig: Bass, 1848), 1.2.17-18, p. 22.

${ }^{80}$ Genealogie 1.3.7. Although the word polisemum is not coined by Boccaccio here, he is the first to form an advanced poetics around it. The term had been used in Dante's Epistle to Cangrande and in many other texts, such as Uguccione da Pisa's Derivationes and Servius's commentary on the Aeneid. See Ernst R. Curtius, European Literature and the Latin Middle Ages, trans. Willard R. Trask, Bollingen Series 36 (Princeton: Princeton University Press, 1933; repr. 1990), 357 n. 24.

${ }^{81} \mathrm{On}$ the twelfth-century mode of speech known as the integumentum see Winthrop Wetherbee, "Philosophy, Cosmology, and the Twelfth-Century Renaissance," in Peter Dronke, ed., A History of Twelfth-Century Western Philosophy (Cambridge: Cambridge University Press, 1988), 21-53, in which he speaks of Bernardus Silvestris, John of Salisbury, and Alan of Lille. The poetics of obscurity that the integument characterizes was proper to philosophical discourse, while allegory was proper to theological discourse. On the relationship between philosophy and poetry in the twelfth century see also Wetherbee, Platonism and Poetry, 66-73, as well as his more recent "Philosophy, Commentary, and Mythic Narrative." Stock also offers a useful discussion of the topic of narratio fabulosa in Myth and Science, 11-62.

Speculum 87.3 (July 2012) 
but are saturated with various different meanings. As an example of the polysemy of myth, Boccaccio offers a fourfold interpretation of the myth of Perseus's killing of the Gorgon, moving from the literal to the moral to the allegorical and finally to the anagogical sense:

Perseus Iovis filius figmento poetico occidit Gorgonem, et victor evolavit in ethera. Hoc dum legitur per licteram hystorialis sensus prestatur. Si moralis ex hac lictera queritur intellectus, victoria ostenditur prudentis in vicium et ad virtutem accessio. Allegorice autem si velimus assumere, pie mentis, spretis mundanis deliciis, ad celestia elevatio designatur. Preterea posset et anagogice dici per fabulam Christi ascensum ad Patrem, mundi principe superato, figurari. Qui tamen sensus et si variis nuncupentur nominibus, possunt tamen omnes allegorici appellari.

In the poetic fiction, Perseus, the son of Jove, killed the Gorgon and flew to heaven a victor. As long as this is read through the letter, it offers a historical sense. If a moral understanding is sought literally, then the victory of the prudent man over vice and his ascension to virtue are shown. But if we wish to take it allegorically, the rising of the pious mind, after it has shunned the delights of the world, is depicted. Finally one could also say anagogically that through the myth the ascension of Christ to the Father, after he conquered the prince of the world, is figured. These senses, even if they are called by various names, can nevertheless all be called allegorical. ${ }^{82}$

Boccaccio never actually employs the fourfold method of interpretation in the Genealogie, but by invoking it, he both shifts the truth value of mythic discourse closer to that of the Bible and places the focus of interpretation on the letter, through which one arrives at the sensus hystorialis.

Although it was generally the case that the anagogical sense was the most important of the four kinds of meaning - the other three of which were the literal, moral, and tropological-Alastair Minnis's work on the commentary tradition has demonstrated that this was a matter of debate in the late Middle Ages and that the literal or historical sense increasingly became seen as the foundation for further allegorical interpretation. ${ }^{83}$ Minnis has pointed out that the literal offered a sense of certainty that the other senses could not provide. The idea of certainty in the commentary tradition can be connected to Boccaccio's own reading

\footnotetext{
${ }^{82}$ Genealogie 1.3.8. This is clearly a remaking of Dante's example of the allegory of the theologians in his Epistle to Cangrande. On this passage and the Dantean intertext see Mazzotta, "Boccaccio," 359-60. On the fine line between historia and fabula see also Kriesel, "Boccaccio's Theory of Allegory"; Hyde, "Boccaccio," 743; and Peter G. Bietenholz, "Historia" and "Fabula": Myths and Legends in Historical Thought from Antiquity to the Modern Age, Brill's Studies in Intellectual History 59 (Leiden: Brill, 1994), 151-56.

${ }^{83}$ Alastair Minnis discusses a fifteenth-century Spanish commentator, "El Tostado," on 244-48 of "Quadruplex sensus, multiplex modus: Scriptural Sense and Mode in Medieval Scholastic Exegesis," in Whitman, ed., Interpretation and Allegory, 231-56, noting that "the sensus litteralis is the only 'immediate sense,' whereas the other three are 'mediate,' since they are signified by the things which 'the letter' signifies" (244). See also his discussion of Nicholas of Lyre on 248-56 of the same essay. For a more extended discussion of Scholastic literary theory see Minnis's Medieval Theory of Authorship, esp. 73-117, on the "literal sense"; and Minnis, Scott, and Wallace, Medieval Literary Theory, in which the editors trace the problem of literal truth and intentionality in the interpretation of biblical and classical texts. On the four senses of biblical interpretation see Henri de Lubac's classic study Medieval Exegesis: The Four Senses of Scripture, trans. Mark Sebanc and E.M. Macierowski, 3 vols. (Grand Rapids: Eerdmans, 1998-2009).
}

Speculum 87.3 (July 2012) 
of the integumental allegory in the Genealogie. Proper to the interpretation of literary or philosophical texts, the integument allowed for multiple interpretations of the poetic image or word. Although it was based on the practice of the fourfold interpretation of the Bible, it was slightly different, as is explained in the twelfth-century commentary on Martianus Capella's De nuptiis Philologiae et Mercurii attributed to Bernardus Silvestris:

Est autem allegoria oratio sub historica narratione verum et ab exteriori diversum involvens intellectum, ut de lucta Iacob. Integumentum vero est oratio sub fabulosa narratione verum claudens intellectum, ut de Orpheo .... Allegoria quidem divine pagine, integumentum vero philosophice competit.

An allegory is a discourse beneath a historical narration that involves a true meaning and a meaning that is different from its exterior, as (is seen) from Jacob's struggle. But an integument is a discourse beneath a fictive narration that hides the true meaning, as (is seen) from Orpheus .... Allegory then is proper to holy writing while the integument is proper to philosophical writing. ${ }^{84}$

The important difference here is that the biblical narration is read as true on a historical level, while the poetic narration is not, since it bears truth only on an allegorical plane. For Boccaccio, however, whose primary method of interpretation is euhemeristic, or at least broadly historicist, mythic narrations are directly traceable to an original historical moment, making them in effect narratives that unveil the historicity of their creation. Like biblical narration, myths are true historical narratives. So, by calling mythic meaning "polisemum" and by offering a fourfold reading of Perseus's struggle with the Gorgon, Boccaccio is expanding the integumental interpretative practice to include truth on the literal and historical level. He is in effect attributing a literal truth to the fictional narratives. Moreover, in the description of multiple meanings of the integumentum Boccaccio seems to value the literal over the others by calling it the "sensus primus." From the historical perspective that Boccaccio takes, this sense is first in that it is the most archaic and thus the most related to the poetic narration on the cortex. From the point of view of a literalistic or historicist interpreter of myth, it is also first in the practice of interpretation since it is the basis from which all other senses may be understood. The other meanings, Boccaccio says, can be found only "per significata," or "through what is signified" by the literal meaning taken from the cortex. The historical sense, then, is the original sense on top of which others grow, making the further ethical and natural allegories-in a sense-allegories of history. The traditional hierarchical structure of the integumentum, then, is almost turned inside out, with the human acts of creating given priority at the center. ${ }^{85}$

\footnotetext{
${ }^{84}$ The Commentary on Martianus Capella's "De nuptiis Philologiae et Mercurii" Attributed to Bernardus Silvestris, ed. Haijo Jan Westra, Studies and Texts 80 (Toronto: Pontifical Institute of Medieval Studies, 1986), 45.

${ }^{85}$ For a different discussion of Boccaccio's understanding of the integumentum see Mazzotta, "Boccaccio," 351-52, where he refers to the concept of equivocationes, or alternate meanings under one name, in Bernardus's commentary on the Aeneid. Although Boccaccio's reading of mythic allegory as polysemous may have been influenced by Bernardus's thought, it is not quite the same. Boccaccio gives primacy to the historical and describes a dependence and connectivity between the
} 
Although Boccaccio recognizes the moral, allegorical, and anagogical senses in his brief reading of the Perseus myth, grouping them all under the category of allegory, he says that he does not intend to talk about them all: "Verum non est animus michi secundum omnes sensus enucleare fabulas que sequuntur, cum satis arbitrer unum ex pluribus explicasse, esto aliquando apponentur fortasse plures" "But it is not my intention to explain the fables that follow according to every sense, because I think that it is enough to explain one of the many senses, although at times perhaps many may be added"). ${ }^{86}$ The plures sensus of which he speaks-beyond the letter of history but bound to that letter-are the moral and the physical, as he explains much later on in book 15: "circa honesta eorum theologia versetur, que sepissime potius physiologia aut ethologia quam theologia dicenda est, dum eorum fabule naturalia contegunt aut mores" ("when the theology of the Ancients will be seen to exhibit what is right and honorable, though in most cases it should be considered rather physiology or ethology than theology, according as the myths embody the truth concerning physical nature or human"). 87 The one sense- "unum ex pluribus"-that is at the basis of his allegorical accounts is the sensus hystorialis, from which the natural and ethical allegories grow. The sensus hystorialis, however, may be interpreted in at least two ways. It is the sense of history in that it recounts an event that literally took place. Yet it is also a meaning that unveils its own becoming in time-a narrative sense. The historical sense of a myth recounts the times, places, and personages of the past, and in so doing it is dependent upon contextualization of those elements. ${ }^{88}$ By interpreting a myth historically, Boccaccio focuses on the temporal, spatial, and human elements that give the story its meaning. His reading of ancient myth is grounded in an understanding of the historicity of the truths that myth communicates. When Boccaccio unravels the meaning of a myth, then, he is also exposing a historical continuum of meaning. The temporal and spatial

\footnotetext{
various allegorical meanings, whereas Bernardus allows only for the copresence of different meanings under the same name. On the late-medieval debate about the primacy of various modes of allegorical interpretation see Minnis, Quadruplex sensus. Boccaccio's respect for the literal sense is similar to that of Hugh of St. Victor (Didascalicon 5.2-4) and Nicholas of Lyre (Glossa ordinaria et Postilla Nicolai Lyrani, second prologue), both of whom, for all their differences, speak about the literal/historical sense as the foundation of allegorical interpretation. Both use the metaphor of a house builder to describe the work of interpretation. See Minnis, Scott, and Wallace, Medieval Literary Theory, 65-67 (Hugh of St. Victor) and 204 (Nicholas of Lyre).

${ }^{86}$ Genealogie 1.3.9.

${ }^{87}$ Genealogie 15.8.4, trans. Osgood, 123.

${ }^{88}$ Boccaccio's understanding of the sensus hystorialis is most certainly in dialogue with Dante's employment of the historical sense, not only in the Epistle to Cangrande, but also in Purgatorio 10, where he uses the terms "storia" and "storiato" to describe the exemplary images of humility on the terrace of pride. See Giuseppe Mazzotta, Dante, Poet of the Desert: History and Allegory in the "Divine Comedy" (Princeton: Princeton University Press, 1979), 237-42. Mazzotta writes that for Dante "the primary sense of the word 'storia' ... is representation" or narrative (241). The images created by God in purgatory act as a model for Boccaccio's understanding of the myths of the ancients, which are the historical transcription of the symbolic meaning of God's creation. On history and myth in Dante see also Joan Ferrante, "History Is Myth, Myth Is History," in Michelangelo Picone and Tatiana Crivelli, eds., Dante: Mito e poesia (Florence: Cesati, 1999), 317-33.
}

Speculum 87.3 (July 2012) 
elements of the historical sense become evident on a theoretical level when one considers why Boccaccio embedded his theory of allegory three chapters into his treatise, in the middle of a discussion of Discord.

The apparently casual tangent in which Boccaccio explains his working theory of allegory is in fact indicative of how he viewed the historicity of allegorical meanings. By embedding his theory in this chapter, Boccaccio makes Discord the embodiment of the process of determining the allegorical senses within a myth-the embodiment of interpretation. The direct progeny of Demogorgon, a figure for Natura naturans, Discord sprang forth out of the "Eternitatis antro" and the "utero Chaos" ("the cave of Eternity" and "the uterus of Chaos"), which, as noted above, respectively represent the senseless accumulation of time and of the primordial matter of nature. Like the process of unraveling the knots of allegorical sense, which Boccaccio describes, Discord represents the separation of the amassment of time and materiality that form the world. ${ }^{89}$ Boccaccio writes of the god: "Patet igitur hoc ante alia fecisse: disgregasse scilicet que inter se erant elementa confusa, calida enim frigidis, sicca humidis, et levia gravibus repugnabant" ("It is clear then that he did this before other things; that is, he separated the elements that were confused among themselves, for hot things were incompatible with cold things, the dry with the wet, and the light with the heavy")..$^{90}$ Discord, then, may be interpreted as a simple figure for the disintegration of diverse elements according to quality. Boccaccio goes on to explain that Demogorgon pulled Discord out of the uterus of Chaos in order to "que immixta erant certo ordine segregare" ("segregate in a certain order the things that had been mixed up"), and he did this first because Discord "totiens aufertur a rebus quotiens, amotis discordantie causis, illis debitus imponitur ordo" "is removed from things every time the causes of dissonance are removed and the due order is imposed on them"). ${ }^{91}$ By removing the principle of discord from the primitive time and matter of nature, Demogorgon's birthing of Discord establishes a primitive ordering of time and matter.

The process of allegorical interpretation is similarly one of distinction by which chaotic elements are separated from a confusing mass of possibilities, both temporal (Eternity) and material (Chaos). Born along with Discord are the Parcae and Pan, each of which bear specific qualities of the progenitors: the Fates organize time, and Pan governs the materiality of the earth. Yet each is separated from the primal, creative matter of the universe, Demogorgon, by the principle of distinction embodied by Discord. We must understand Boccaccio's explanation of allegoresis in this chapter as mimetic of its context. Earlier in his explanation of allegorical interpretation, Boccaccio had quoted Macrobius's dictum that "inimicam esse nature apertam undique expositionem sui" " "it is contrary to nature to explain her openly all over"). ${ }^{92}$ In teaching his patron about allegory Boccaccio

\footnotetext{
${ }^{89}$ Intuiting the connection between the material treated and the manner of treatment, Mazzotta points out that Demogorgon, his companions, and his children represent "the genealogy of the imagination as primordial chaos, which does not come from something else, and from which the myths come into being": "Boccaccio," 359.

${ }^{90}$ Genealogie 1.3.11.

${ }^{91}$ Genealogie 1.3.10.

${ }^{92}$ Genealogie 1.3.6; Macrobius, Commentarium in Somnium Scipionis 1.2.17-18, p. 22.
}

Speculum 87.3 (July 2012) 
similarly avoids an overt explanation of how to interpret the secrets that poetry hides. He opts instead for one that both hides and exposes its nature rhetorically, so that we might understand that allegorical interpretation is the process of separation of the chaotic elements of myth into both a historical, or temporal, order and a spatial, or geographical, order. ${ }^{93}$

The multiple meanings that the mythic characters in the Genealogie bear within them are ordered according to a principle of temporal and spatial segregation. Each character acts as a sieve that captures fragments of human culture in separate times and places. Through the use and reuse of these archaic metaphors, poets re-create a fragmentary continuity between ancient and modern, through the reliance on a human logos, an anthropology of myth. Giuseppe Mazzotta has noticed the similarity of Boccaccio's idea of polysemy to Bernardus Silvestris's explanation of equivocatio and multivocatio, whereby many different meanings might coinhabit a single name or, in the second case, the same meaning might be called by many different names. ${ }^{94}$ For Boccaccio, however, I contend that this multiplicity of meanings (a poetic chaos of sorts), when it is reconstructed historically and genealogically (by inserting a principle of discord), becomes polychronic, in that it gathers together meanings as they have developed over time and space. Unlike Bernardus Silvestris's idea of equivocatio or multivocatio, Boccaccio's concept of polysemy allows for myths to signify synchronically the different meanings that have accrued diachronically. This is to say that mythic personages are articulations of culture that change and grow in time, aggregating new meaning in layers as a shell accumulates the minerals of the sea, so that the integument becomes a historical as well as an epistemological artifact. So, for many of the deities, there are multiple instantiations of each god, or multiple names are given to the same concept, each belonging to different generations of human society in different geographical locations. It is Boccaccio's job as a scholar to unravel the polychronic knot so that each articulation may be understood diachronically in its proper place on the genealogical tree.

The expositions of the remaining gods in the Genealogie are temporal and spatial instantiations of an individual god's name or meaning. For example, instead of speaking merely of the multiple names associated with Natura naturata or the earth-simple multivocatio-Boccaccio locates each naming on both temporal and spatial planes. In the case of equivocatio, the mythographer separates diverse instantiations of the same name, such as the three Joves, and locates them

\footnotetext{
${ }^{93}$ It is not my intention to examine here the geographical movement of mythic figures in the Genealogie. A key example of the geographical and temporal expansion of an individual god is Mercury, whose six instances move from Greece to Egypt to France along a spatial itinerary parallel to that of the translatio studiorum. I am currently revising for publication a paper on this aspect of Boccaccio's exposition of Mercury, entitled "Boccaccio, Ethnographer? The Example of Mercury," presented at the American Boccaccio Association's 2010 International Boccaccio Conference held at the University of Massachusetts, Amherst. Boccaccio's geographical dictionary, De montibus, silvis, fontibus, lacubus, fluminibus, stagnis seu paludibus et De diversis nominibus maris, ed. Manlio Pastore Stocchi, in Tutte le opere, 8:1815-2122, acts as a compendium of the places of myth in the Genealogie.

${ }^{94}$ Mazzotta, "Boccaccio," 352.
}

Speculum 87.3 (July 2012) 
in different times and places of the human imagination. In the remaining pages I will propose a reading of these two figures, Natura naturata and Jove, that demonstrates how Boccaccio's temporal allegories trace a history of the human imagination.

In the same way that Boccaccio described the creation of Demogorgon as a figure for Natura naturans in a temporal process that moved from marvel to fear to contemplation, with Pan he similarly describes a historical transition from the contemplation of Natura naturans to that of Natura naturata. The majority of Boccaccio's exposition of Pan treats the significance of his body, or ymago, in poetic descriptions. Boccaccio describes Pan as having horns, a red face, a long beard, spotty skin, a hairy body, and as carrying a fistula, or reed pipe, and a staff because the ancients wished to describe the "universale nature corpus tam scilicet agentium quam patentium rerum" ("universal body of nature, that is both [the nature] of the things that act and [the nature] of the things that experience acts"). ${ }^{95}$ In the philosophical order of knowledge, Pan is a representation of nature in its corporality and historicity-all the things of nature that act and are acted upon. Boccaccio interprets the horns, which point heavenward, as having signified a "supercelestium corporum demonstrationem, quam duplici modo percipimus, arte scilicet, qua discursus syderum investigantes cognoscimus et sensu quo eorum in nos infusiones sentimus" "demonstration of the celestial bodies, which we perceive in two ways, that is, by means of art, by which we know the courses of the stars, and by means of the senses, by which we feel their influences on us"). ${ }^{96}$ By demonstration (literally a "showing"), the fiction opens up a vision of the celestial bodies that were perceived both by the mind and by the body. With Pan's red face the ancients meant the element of fire, with his beard the active power of fire, and with his spotty skin the heaven of the stars, which covers the things "ad naturam rerum spectantia" ("that belong to the nature of things"). His staff signified the governing order of nature ("nature regimen"); his fistula indicated celestial harmony; and finally his hairy body represented "terre superficiem montium et scopulorum gibbosam et silvarum virgultorum et graminum tectam" ("the bulging terrestrial surface of mountains and rocks, which is covered with forests, bushes, and grasses"). ${ }^{97}$ Boccaccio finds that in the primitive imagination Pan signified elemental nature, from the realm of the stars down to the forested mountains. Within the temporal structure of the Genealogie, all of the meanings that Boccaccio deduces from Pan's figure are seen to have developed historically over time. For Boccaccio, the god denotes a historical transition that took place from the earlier worship of the generative power of nature in Demogorgon to the worship of nature in its effects.

Boccaccio interprets the meaning of Pan in the philosophical order-Natura naturata emerging from Natura naturans-as an anthropological development in the perception of reality. Through a process of historical change, Boccaccio

\footnotetext{
${ }^{95}$ Genealogie 1.4.10.

${ }^{96}$ Ibid.

${ }^{97}$ Genealogie 1.4.12.
} 
relates, the ancient Arcadians came to worship Pan so much that they put him in the place of Demogorgon as father of the gods:

hunc Pana, seu quod in processu eundem cum Demogorgone arbitrarentur Arcades, ut Theodontio visum est, seu quod illo neglecto in istum totos verterent animos, sacris etiam horrendis, ut-puta-humano, imo natorum, illi litantes sanguine, precipue coluere, eumque dixere Pana e pan, quod totum latine sonat, volentes ob hoc quod omnia quecunque sint in nature gremio concludantur, et sic ipsa totum sit.

They especially worshiped this Pan, either because the Arcadians began to think of him as the same as Demogorgon, as is seen in Theodontius, or because they neglected the latter and turned their whole minds to the former, praying to him even with horrendous sacrifices, such as with human blood, or even the blood of children. They called him Pan from pan, which in Latin we say totum (everything), wanting this to mean that everything that exists in nature is enclosed in his bosom, and thus that it (nature) is everything. ${ }^{98}$

After a passage of time ("in processu"), later generations of Arcadians, who had created Demogorgon to represent an incomprehensible and awesome nature, began to worship Pan as the creator of all things. The wonder that the earlier Arcadians had experienced within the caves of the earth is translated into ritual by the horrific quality of their sacrifices. Boccaccio goes on to explain that more recent authors changed Pan's name because of the human propensity for innovation: "Iuniores inde, eo quod innovata placeant, Pana Lyceum vocaverunt. Alii, dempto Panis nomine, Lyceum tantum dixere" ("More recent men, since things that are altered are pleasing, called him Pan Lyceum. Others took away the name Pan and called him Lyceum alone"). ${ }^{99}$ The renewal and change of name in the myths of the earth reflect how Natura naturata came to be perceived differently over time and within different cultures.

In the first book of the Genealogie, the last of the major mythic instances of the nature of things (rerum natura) that actually gives rise to a family of gods is Terra, the eighth child of Demogorgon. The story of her birth together with Discord, Pan, and the Parcae is the result of the imagination of a later epoch than that of the creators of Pan. She is the natural principle of the earth, which later men who fashion themselves as sky gods will imagine as their wife. ${ }^{100}$ In time she became known to later generations under many names (i.e., multivocatio): "Vocavere eam preterea multis nominibus, ut puta Terram, Tellurem, Tellumonem, Humum, Aridam, Bonam deam, Matrem magnam, Faunam et Fatuam. Habet et preter hec cum quibusdam deabus communia nomina. Dicitur enim Cybeles, Berecinthia, Rhea, Opis, Iuno, Ceres, Proserpina, Vesta, Ysis, Maia et Medea" ("They called her later on with many names, such as Terra, Tellus, Tellumo, Humus, Arida, Bona dea, Mater magna, Fauna, and Fatua. Besides these

\footnotetext{
${ }^{98}$ Genealogie 1.4.15.

${ }^{99}$ Genealogie 1.4.16.

${ }^{100}$ For example, citing Eusebius, Boccaccio reports that Saturn was an important man who imagined his descent from Coelum and Vesta (one of the later names of Terra) in order to amplify the fame of his name and consolidate his power. Boccaccio also mentions another possibility, citing Lactantius, that Saturn's mother was Terra because the ancients called people sons of the earth if they were of uncertain origin. See Genealogie 8.1.3 and 6.
}

Speculum 87.3 (July 2012) 
she also has names in common with some goddesses. For she is called Cybele, Berecinthia, Rhea, Opis, Juno, Ceres, Proserpina, Vesta, Isis, Maia, and Medea"). ${ }^{101}$ Terra takes over from Pan as the representation of the rerum natura. This is why they called her the Great Mother, as Boccaccio explains in one of his etymological allegories derived from Isidore of Seville. ${ }^{102}$ Nature's power and effects, which had previously been worshiped under the name of Demogorgon and then Pan, finally become Terra, to whom all the earth goddesses of subsequent antiquity trace their meaning. The poet-theologians, whose intentions Boccaccio endeavors to retrieve, lived at some imprecise moment of antiquity after those men who invented Demogorgon and Pan, and they replaced cults of those gods with Terra, making her a goddess of generative nature.

Although Boccaccio is imprecise about the period in which this takes place, he gives two possibilities for the historical circumstances that led to Terra's creation:

Dicunt eam Titanis, qui sol est, coniugem, eo quod in eam sol agat tanquam in dispositam materiam ad producendum animantia quecunque atque metalla et preciosos lapides et huiusmodi. Non nulli volunt Titanum hominem ingentis potentie fuisse et terre virum dictum eo quod multum terre possideret, et filios suscepisset tanta prestantes fortitudine et corporis mole ut non ex muliere sed ex ingentiori corpore, ut-puta-terre, suscepti viderentur.

They say that she was the wife of Titan, who is the sun, because the sun acts on her as on material that is disposed to producing animate beings and metals and precious stones and similar things. Many find that Titan was a man of great power and was called a man of the earth, because he possessed many lands, and he had generated children of such great strength and bodily mass that they seemed to have been born, not from a woman, but from a much larger body, such as that of the earth. ${ }^{103}$

Terra was believed to have been the wife of Titan perhaps because the ancients saw a natural principle being demonstrated between the sun and the earth-the earth, in order to create, needed the heat of the sun—or perhaps because she was imagined as such by those in the age of the man Titan, who was the father of the Giants. ${ }^{104}$ The philosophical order of knowledge-the physical interaction of the sun and the earth-is linked within the myth to the historical progression of human perception. The imprecision of Boccaccio's efforts to establish the historicity of the invention of Terra is due to the phenomenon of multivocatio, which over time led to the confusion of different aspects of the earth, both as a natural body and as a figure for human relations.

In different generations of the human imagination Terra was said to have given birth "ex incerto patre" ("from an unknown father") to five children: Night, Fame, Tartarus, Antaeus, and Tages. The uncertainty of the paternal origins of these gods indicates for Boccaccio a temporal confusion, in which later generations made use of the name Terra in order to explain either historical or natural

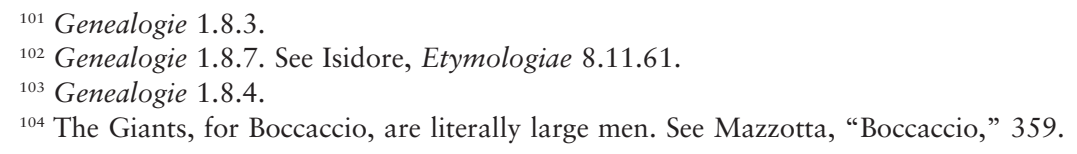


phenomena related to the earth. ${ }^{105}$ In this respect, the last of the offspring of Terra is an interesting example of how, for Boccaccio, myth allows for a unique relationship between the human historical order and the philosophical order of nature. Through his euhemeristic anthropological interpretations, he shows how historical men of much later generations were imagined to have been the sons of the earth. Tages, Boccaccio recounts, was added by the Etruscans to Terra's line because an Etruscan farmer, while digging in a field, found a child with miraculous powers that caused a sense of wonder in those who saw him:

apud Etruscos in agro tarquiniensi aliquantulum tellus intumuisset, is villicus cuius erat agellus novitate rei permotus avidusque videre quid esset ostenti monstratura turgiditas aliquandiu expectavit, tandem impatiens more, ligone sumpto, locum cepit sensim effodere, nec multum effodit, et ecce ex glebis prosilvit infantulus. Quo monstro perterritus rudis homo vocavit affines, nec diu et is, qui modo infans erat, etate provectus visus est, et inde senex, et cum incolas aruspicinam docuisset, repente nusquam comparuit. Auditores autem arbitrati numen et terre credidere filium et nominavere Tagetem, quod idem olim lingua sonabat etrusca, quod latina deus; eumque postea loco summi numinis coluere.

When the land of the Etruscans, in the territory of Tarquinia, was a little swollen, the farmer who owned the land was struck by the novelty of the matter and was curious to see what marvel that swelling was going to show, so he waited a while, but in the end, impatient from the wait, he took up a hoe and began to dig in that place little by little. He had not dug for long when there jumped out of the soil an infant. Terrified by this wonder, the primitive man called his neighbors, and it was not long before he who was an infant seemed to advance in age and then to be an old man. And after he had taught the uncivilized men the art of divination, he suddenly disappeared. Those who had heard him thought that he was a god (numen) and believed him to be the son of the earth and called him Tages, which at that time meant in the Etruscan language what in Latin is written deus (god); and afterwards they worshiped him as a supreme $\operatorname{god}$ (numinis). ${ }^{106}$

Boccaccio explains that this myth (figmentum) is the result of a historical individual who appeared suddenly among the Etruscans-perhaps out of a caveafter having abandoned the company of men in order to study the art of haruspicy. The common crowd (rudus vulgus) believed him to have been born from the earth, and so he was called a son of Terra. Having established a temporally defined genealogical connection between the philosophical order of nature and the beliefs of the common crowd, Boccaccio proceeds to derive an anthropological truth about the customs of the ancients: "Consuevere preterea veteres exteros

${ }^{105}$ Boccaccio does not specify how Night came to be but offers an explanation of the night's natural association with the sun, which was recorded by myth in the fable of the shepherd Phanes's love affair with her. Fame's association with Terra began with the fables about the war between the Titans and Jove. Tartarus was associated with the earth from early on because of the caves of the earth and the horror that grew within it, which they then associated with the punishment of souls in the afterlife. Finally Antaeus, a historical individual, was believed to be a son of Terra because he was an expert at wrestling. He may have also been associated with Terra after his death, since in Libya at Tingis, or Tangeri, his grave was thought to have been a hill that resembled the figure of a man.

${ }^{106}$ Genealogie 1.12.1-2.

Speculum 87.3 (July 2012) 
ignotos terrestri itinere ad se venientes Terre filios vocitare" "The ancients were accustomed to calling sons of the earth unknown foreigners who came to them by a land road"). ${ }^{107}$ The generative powers of the human imagination connect Tages genealogically with Terra, who is in turn related to the original figure for Natura naturans, even though the deified man emerges in a more recent generation of mythmakers. The sensus hystorialis of this myth is not only euhemeristic but also an indication that the myth narrates its own historicity-that is, its position within the history of figures of the earth. By resorting to cultural arguments in his explanation, Boccaccio shows the anthropological nature of his inquiry. The deification of Tages records a historical moment within the Etruscan culture, and his myth protects and sublimates haruspicy as a central aspect of that civilization: "Eum autem deum habitum ob id contigisse puto, ut doctrinam quam summe colebant deo autore nobilitarent" "That he was held to be a god, I think, depends on the fact that they [the Etruscans] ennobled with the authority of a god the doctrine that they most highly honored"). ${ }^{108}$ The explanation of the fable is a clear example of how Boccaccio ties the origins of myths to the historical processes within which the imagination functions. For him the ancient myths that originated in the worship of nature lead through time to Tages. Terra had other children associated with her by the ancients, but according to Boccaccio either they were born to her under a different name at a different time and placesuch as Vesta, Gaia, Rhea, or the many others mentioned above-or they have a definite father, with whose line they are associated. ${ }^{109}$

Boccaccio's temporalization of multivocatio across the genealogical divisions of this treatise is often quite hard to follow, given the great number of names for certain kinds of divinities like the earth, the moon, and the sun. ${ }^{110}$ Equivocatio, however, is more easily followed, since the same name is repeated in different contexts. The temporal and spatial dimensions of a mythic character become even clearer in these cases. ${ }^{111}$ Here I will take as examples of a temporal extension of equivocatio the three instances of Jove to which Boccaccio dedicates chapters. Although he mentions at least five historical instantiations, he recognizes only three of them as divine. Instead of considering Jove's function within a single literary work, such as Ovid's Metamorphoses, or within a single philosophical

${ }^{107}$ Genealogie 1.12.4.

${ }^{108}$ Genealogie 1.12.5.

${ }^{109}$ Her children, born to her under the name Terra, are Styx (fathered by Acheron in the line of Coelum, 3.14), Acheloos, Inachus, Peneus, Nilus, Alpheus, Crinisius, Tiber, Axius, Asopus, Cephysus, Meander, and Sperchius (fathered by Ocean in the line of Coelum, 7.19, 21, 27, 30, 44, 48, 50, 52, $55,58,60$, and 63 ). All of these, it is worth noting, are rivers that Boccaccio says were historically associated with both the earth and the ocean.

${ }^{110}$ Other than the earth, the moon and the sun are also key examples of multivocatio across time and space. The moon is mentioned as a referent for the following gods across the temporal continuum of the treatise: Argentea, Arthemis, Ceres, Diana, Hecates, Lucina, Mena, Phebe, Proserpina, and Trivia. The sun is figured by the names Sol, Phoebus, Loxias, Lycius, Socomas, Argitorosus, Horus, Imbricitor, Apollo, and Liber.

${ }^{111}$ Jove and Mercury are the clearest examples of Boccaccio's temporal treatment of equivocatio in the Genealogie, but he sometimes does not follow through with all of the instances of a given god's name. For example, he notes two first Dianas and omits the fourth Minerva. 
paradigm, such as Macrobian Neoplatonism, Boccaccio's historical approach allows him to understand the contradictions in the character and in its various poetic uses as having developed over time. He begins his historical analysis of the myth's meaning by connecting Jove to an original moment in primitive Greek political history:

hunc ante quesitum maius nomen Lysaniam nuncupatum, hominem arcadem et profecto nobilem, et ex Arcadia Athenas ivisse, et cum esset ingentis ingenii, vidissetque rudi in seculo rudi et fere bestiali ritu viventes Atticos, ante omnia compositis legibus illos publico instituto vivere docuit, et qui feminas fere communes habebant, primus matrimonia celebrare monstravit, et cum iam ad humanos redegisset mores, monuit eos deos colere, et eis aras et templa atque sacerdotes instituit et multa insuper illis ostendit utilia. Que dum mirarentur silvestres Attici atque commendarent, eum rati deum, Iovem vocavere, regemque suum fecere.

Before he had his greater name, he was called Lysanias, an Arcadian man who was certainly noble and who had gone from Arcadia to Athens; and since he was of great genius and had seen that the Greeks of Attica lived, in a barbarian time, in a barbarian and bestial manner, he first composed laws and then taught them to live by public institutions. To those who held women in common, he was the first to show how to celebrate matrimony, and once he had redirected them to human customs, he taught them to worship the gods and instituted altars, temples, and priests for them, and he showed them many more useful things. Thence the savage Greeks of Attica held these things in wonder and praised them. Thinking that he was a god, they called him Jove and made him their king. ${ }^{112}$

In a move that expands the temporal dilation of ancient history, this Jove is considered separately from all other instantiations of the god throughout early human history. The original Jove became worshiped as a god for his ethical virtues, for guiding primitive people to "humanos ... mores." The civic ethics that Jove represented in his human life and that he came to symbolize as a god are the original causes of his great name, as Boccaccio goes on to explain, because the name Jove, and its derivative Jupiter, comes from iuvans, or iuvans pater, "father who helps." 113 Despite the error of this religious belief from a Christian point of view, it indicates to Boccaccio the manner in which early human societies understood ethical virtue and how the memory of virtuous men was preserved through myth. In fact, as Boccaccio will go on to say, the virtues represented by Jove could also be attributed to the Christian God.

Furthermore, Boccaccio connects the "ethological" history of the man worshiped as god to the "physiological" understanding of Jove as a planet: "a similitudine scilicet operationum conformium huius hominis ipsi Iovi" ("it is clear that by similarity the operations of this man conform to those of the planet Jove"). ${ }^{114}$ He goes on to compare the natures of the man and the planet:

${ }^{112}$ Genealogie 2.2.1-2.

${ }^{113}$ Genealogie 2.2.9. This is a common etymology that Boccaccio received from Isidore of Seville. See Etymologiae 8.11.34.

${ }^{114}$ Genealogie 2.2.5-6.

Speculum 87.3 (July 2012) 
Iovem planetam natura calidum esse et humidum, aereum, temperatum, modestum atque honestum, laudabilem plurimum et patientie observatorem, ac in periculis post patientiam audacem, liberalem misericordem, cautum, amatorem verum, magistratum avidum, fidelem, multiloquum, bonorum amicum, malorum vero hostem, amatorem principum et maiorum ... eum significare naturalem animam, vitam, pulchritudinem, sapientes viros, legum doctores, iustos iudices, divinum cultum, religionem, victoriam, regnum, divitias, nobilitatem, gaudium et huiusmodi. Quibus consideratis, et demum huius hominis ponderatis moribus, adeo eum cum Iove convenire discernemus, ut non incongrue Iovem nuncupatum dicamus, et hanc convenientiam tanti nominis illi causam fuisse credamus.

Jove the planet is hot by nature, airy, temperate, mild, and well formed, and the man Jove is very praiseworthy and an observer of patience, and after patience he is bold in the face of dangers, liberal, merciful, cautious, a true lover, avid of magistracies, faithful, loquacious, friend of the good, enemy of the bad, lover of princes and of the powerful, ... and he signifies the natural soul, life, beauty, wise men, doctors of the law, just judges, the divine cult, religion, victory, kingdom, wealth, nobility, joy, and so on. Having considered these things and having pondered the customs of this man, we discern that he is in agreement with Jove, so that we can say that he was congruously called Jove, and we believe that this agreement was the cause of so great a name. ${ }^{115}$

Like the list about the creative effects of the earth, the lists that describe the planet and the man here are meant to be hyperbolic. The very excess of qualities that both entities possess is what causes them to be melded into one mythic persona. In this sense the myth is a metaphor that encapsulates an initial surplus of meaning. The ethical and the natural meanings are bound up in the very name under which the man was originally allegorized into a god. Their truths reflect and confirm one another. It is through the historical man's character, however, that Boccaccio reaches what is meant allegorically by the name. His method is a temporal de-allegoresis-a historical unraveling of the meaning veiled by the poetic naming of the man and the planet.

After drawing a parallel between the man and the planet, Boccaccio begins the temporal division of Jove's character by separating the intentions of the first ancients from those of more recent ones:

Sane nomen hoc, postquam ab antiquis planete et Lysanie concessum est, non nullis aliis a recentioribus etiam attributum legimus, ut-puta-Iovi secundo ... et Iovi tercio ... et Pericli atheniensi principi ... et non nunquam ignem et aerem sub Iovis nomine ... inseruere... a prudentioribus etiam summo et vero Deo ascriberetur.

But this name, after it had been given by the ancients to the planet and to Lysanias, we read, has been attributed by more recent men to many others, such as to the second Jove... and to the third Jove ... and to Pericles the Athenian prince, ... and (poets) often inserted fire and air under the name of Jove, ... and it was ascribed by learned men to the highest true God. ${ }^{116}$

\footnotetext{
${ }^{115}$ Genealogie 2.2.6-7.
}

${ }^{116}$ Genealogie 2.2.7-8. 
The ethical model that the historical man offers coincides with the natural allegory from which later poetic fictions derive, even the assertion by learned Christian poets and commentators that Jove is an allegory of the Christian God. Although the primitive ancient peoples are not referred to with the absolute superlative, antiquissimi ("the most ancient"), to differentiate them from more advanced ancient peoples, as was the case earlier, the use of the comparative adjectival form of recentes ("recent") shows Boccaccio's awareness of temporal difference among ancient peoples. The first Arcadians worshiped the god as such, whereas in later periods the term was applied to political men and once again to natural elements. The progression of history in this passage shows how Boccaccio connects the allegorical meanings of the mythic name to specific historical contexts. The character of the man Lysanias, the Arcadian king of Attica, creates a lineage, not only of gods, but of human poetic creation and interpretation. Each variation is an articulation of a specific era's culture.

Immediately following the unfolding of Jove's different meanings for the ancients, Boccaccio reconnects the ancient Jove with the modern Jove, within the fold of the historical development of meaning: "Adeoque in sublime conscendit, ut a prudentioribus etiam summo et vero Deo ascriberetur, nec immerito; ipsi quippe soli tam egregium competit nomen, quod nec abhorret christianus, considerato nominis significato, nisi gentilium fuisset inventum" ("And the name ascended so high that it was ascribed by learned men to the highest true God, and not undeservedly, because to him alone is such an egregious name fitting; and the Christian would not abhor it, once he considered the meaning of the name, if it had not been invented by the gentiles"). ${ }^{117}$ The levels of authority traced within the mythic personage of Jove depend on the human origin of the name and its simultaneous attribution both to a virtuous man and to a powerful planet. The Christian interpreter operates on a twofold level in the lineage that Boccaccio exposes: on the one hand, he is dependent on the genealogy of meaning that traces back to the myth's human origins; on the other, he maintains a privileged viewpoint guaranteed him by his position in universal Christian history. The authority of the ancient and that of the Christian are intricately interwoven. The Christians are literally "more prudent," and thus hold religious authority, but the poetic authority of the name is not based on this prudence. The possibility of signification descends from the contingent human origins of the myth, and the authority of such signification resides in the accumulation and interconnection of the different meanings over time. Boccaccio's exegetical labor consists in laying out diachronically the confused admixture of meaning within each mythic personage and in dividing it into its constituent and interrelated parts.

The fragmented continuity that Boccaccio constructs, however, is not unproblematic for him. He recognizes the difficulty in discerning with precision the historical context within which the first Jove came to be:

${ }^{117}$ Genealogie 2.2.8.

Speculum 87.3 (July 2012) 
Multa preterea poteram hic apponere Iovi a poetis attributa ... sed quoniam ista videntur recte spectare ad ea que de Iove Cretico ficta sunt, illi censui reservanda. Porro, rex inclite, non satis certum est utrum Athenienses Iovem hunc in deum habuerint, aut fecerint. Si autem fecerunt, sciendum est antiquis consuetum fuisse ad augendam originis nobilitatem, conditores civitatum suarum certis suis infaustis cerimoniis numero deorum inserere, et sacris templisque colere.

I could have added here many other attributes given to Jove later on by the poets; ... but since these things seem to point to those attributes that were made up about the Cretan Jove, I judged it better to save them for him. Again, excellent king, it is not certain enough whether the Athenians already had this Jove as god or whether they created him. If, however, they created him as a god, one must know that the ancients were accustomed-in order to increase the nobility of their origin-to ingrafting among the number of the gods, by means of certain unholy ceremonies, the founders of their cities and to worshiping them with sacrifices and temples. ${ }^{118}$

Here the question of the uncertainty of ancient temporality is central to the work of the mythographer, even though Boccaccio does not sufficiently defend his assertion that the Athenians created Jove. This passage shows the close connection between finxere "to make up" and facere "to make" employed across the Genealogie. In the first sentence the poetic attributes are "ficta" (made up) about the Cretan Jove, whereas originally the Athenians "fecerint" (made) Jove by attributing to him divine attributes. Boccaccio's analysis proceeds from the historical origins of the mythic character through the poetic fictions that propagated it in later epochs, thus allowing it to continue genealogically. The meaning in each variation of the myth reflects both continuity and rupture; the various meanings are related to a common origin in time, but they are also rooted in their own historical specificity.

Finally, Boccaccio concludes his section on the first Jove with another affirmation of uncertainty: "Scribunt insuper veteres multos fuisse Iovi filios ... sed cuius Iovis, primi, secundi vel tertii de aliquibus non satis constat ... quos ego illi attribuam Iovi, cui magis videbuntur contemporanei" ("The ancients also write that Jove had many sons, ... but it is not known well enough about some of these sons to which Jove they belong, whether to the first, second, or third; ... but I will attribute them to that Jove to whom they shall seem more likely to have been contemporaries"). ${ }^{119}$ Since Jove is ascribed many offspring in the poetic tradition-a particularly tough problem for medieval commentators on Ovid's Metamorphoses - it is unclear to which one the mythographer should attribute paternity. Nevertheless, Boccaccio's final criterion for the attribution of paternity is another example of his effort to hold to the certainty of history, in that he is guided by a concept of historical appropriateness. In this way, the three Joves of the Genealogie become key markers on a linear time line through which the circular temporality of antiquity (as figured by Eternity in the first book) is straightened out and made comprehensible. They follow generally the time line of the ages of man from the first book of Ovid's Metamorphoses and are

\footnotetext{
${ }^{118}$ Genealogie 2.2.10-11.
}

${ }^{119}$ Genealogie 2.2.11.

Speculum 87.3 (July 2012) 
constantly read historically by comparison with Eusebius's Chronicon, yet the three Joves represent not only the degradation of man from a golden age to an age of warfare and strife but also the confused accumulation of meaning across time. ${ }^{120}$

This interest in historical appropriateness or verisimilitude in the Genealogie can be seen very clearly in the entry on Io, where the ages of the three Joves become a time line for the history of the imagination. After seeking to reconstruct her chronological collocation according to Eusebius's Chronicon, Boccaccio seeks to differentiate Io, daughter of Inachus, from Isis, daughter of Prometheus, whoaccording to Ovid-moved to Egypt:

Quibus [Theodontio et Leontio] et si multum Ovidii obstet autoritas, multum tamen fidei affert inconvenientia temporum. Eusebio enim teste in libro Temporum, Ynacus apud Argos regnavit circa annos mundi III ccc xlvii, eumque annis quinquaginta regnasse dicit Eusebius idem, infra quod tempus Yonem natam necesse est. Potuit hac tempestate Iovem Etheris filium esse ... reliqui vero Ioves diu fuere post istum, ex quibus secundus Ysidi Promethei filie contemporaneus est.

Even though the authority of Ovid stands against them (Theodontius and Leontius), nevertheless the inconvenience of the times offers much credibility. For according to Eusebius in the Chronicon, Inachus reigned in Argos around the year of the world 3347. Eusebius also writes that he reigned for fifty years, in which time Io must have been born. In this time Jove, son of Ether, could have lived, ... but the other Joves lived a long time after this, the second of whom was contemporary with Isis, daughter of Prometheus. ${ }^{121}$

A problem arises, however, when his chronological source finds that Io lived three hundred years later, anno mundi 3647, with the names Hypermnestra and Isis, and that forty-five years into the reign of Cecrops she lay with Jove. Furthermore, Boccaccio relates, in 3783 lived another Hypermnestra, who was also called Isis. He finally concludes that this last period is more appropriate to Isis, and he associates her with the third Jove, declaring his confusion:

Quod quidem tempus satis competit Iovi Cretensi, qui Iuppiter IIIus fuit. Quibus tam diversis hystoriographorum opinionibus fere stupefactus, quid teneam de hac Yside nescio. Hoc tamen scio quia temporis conformitas Ysidis Promethei cum Iove et hystoria, que si non vera est, vero tamen similis est, me magis quam ad aliquam aliarum trahit.

Indeed, this time agrees enough with the Cretan Jove, who was the third. Almost stupefied by these diverse opinions of the historiographers, I do not know what to think about this Isis. I do know this, however: that the conformity of the time of Isis, daughter of Prometheus, with Jove and history (if it is not true, it is nevertheless similar to the truth) brings me more to her than to any of the others. ${ }^{122}$

Despite his lack of the proper tools to determine primitive and ancient history, these passages make clear Boccaccio's efforts at constructing a stable historical

\footnotetext{
${ }^{120}$ On Jove as a “culture-hero" across the ages of man see Tobias Foster Gittes, Boccaccio's Naked Muse: Eros, Culture, and the Mythopoeic Imagination (Toronto: University of Toronto Press, 2008), 64-65. On the principles of order and strife as the primary thematic concern of the Genealogie see Mazzotta, "Boccaccio."

${ }^{121}$ Genealogie 7.22.8.

${ }^{122}$ Genealogie 7.22.10-11.
}

Speculum 87.3 (July 2012) 
context in which myths were created. He is even willing to defy the mythological authority of Ovid in order to read myth as a construction of meaning within a temporal continuum.

The tripartite division of Jove that Boccaccio received from Cicero's De natura deorum presents the mythographer with the problem of relationality. ${ }^{123}$ How do the various instantiations function practically and historically in relation to the others? How does their individual historical context affect the way poets refer to them? Boccaccio encounters great difficulty in establishing the difference in historical context between the first Jove and the second. He knows from Cicero that the second Jove lived in Arcadia and was the son of Coelum (the fictional brother of the first Jove). Coelum was an Arcadian king who had deified himself in order to glorify his name and consolidate his power, but Boccaccio believes that the second Jove's actions must have been great since "absque quibus non potuisset tam insigne meruisse cognomen" ("without them he could not have merited such a name"). ${ }^{124} \mathrm{He}$ nevertheless has found that "pauca ... ad nos usque fama, seu veterum monimenta duxere" ("fame and the monuments of the ancients have brought all the way to us ... few things"), so he looks to Theodontius for a historical and anthropological record of ancient religion. ${ }^{125}$ Theodontius tells him that the second Jove was an Arcadian king who had conquered Lycaon, another king of Arcadia, after he had offered Jove human flesh at a banquet. ${ }^{126}$ His teacher Leontius stated that the second Jove was once called Lysanias; but since Boccaccio identifies Lysanias with the first Jove, he is at a complete loss regarding his real name or his precise historical context: "quid dicam non habeo, nisi ut istas adeo inter se discrepantes opiniones prudentior me, si queat, in concordiam redigat" ("I have nothing to say except that someone wiser than I, if he can, may reduce into harmony these disagreeing opinions"). ${ }^{127}$ In this phrase Boccaccio's effort to maintain historiographical precision is frustrated by the discrepancies in his sources. Instead of eliding the differences, he reports them to his reader, who might be wiser. Boccaccio is interested in demonstrating the plurality of opinions about, and the uses of, mythic names throughout history. Instead of presenting the humanist ideal of a pristine, reborn past, he excavates the past as a grouping of fragments connected in processu from one moment of rupture to another.

Boccaccio concludes the story of the second Jove by referring again to Theodontius, who tells him that the man subsequently moved to Athens, where he became king and waged a war against Coeus, who had become irate when

${ }^{123}$ See Cicero, De natura deorum 3.21.53.

${ }^{124}$ Genealogie 5.1.1.

125 Ibid.

${ }^{126}$ This story is recounted in Ovid's Metamorphoses 1.220. Boccaccio's genealogy of the Titans is very distorted because of the paucity of Greek sources, such as the Bibliotheca by Pseudo-Apollodorus, which would have made it much simpler. In any case, in the Genealogie Lycaon is not the father of fifty sons, as Greek tradition has it, but of a single son. His father is Titan instead of Pelasgus, and he is a brother of the Giants and of Iapetus. Coelum, for Boccaccio, is a stand-in name for Uranus, of whom he had little information besides what he found in Ovid.

${ }^{127}$ Genealogie 5.1.3.

Speculum 87.3 (July 2012) 
Jove raped his daughter Latona, or Leto. ${ }^{128}$ After having defeated Coeus, Jove established a government in Athens worthy of his earlier namesake: "eoque superato [bello] maxima cum gloria, Athenas rediisse, Iovique primo bovem immolasse, et multa ad laudabilem civilitatem spectantia apud Athenienses instituisse; quibus agentibus causis, Iuppiter communi hominum consensu vocatus est" " "Having won that war with greatest glory, he returned to Athens, and he slaughtered a bull to the first Jove, and he instituted among the Athenians many things that are proper to a praiseworthy civilization. Because of these actions, he was called Jupiter by the common consensus of men"). ${ }^{129}$ Initially by venerating the first Jove and then by engaging in a similar ethico-political program, this Athenian king takes on the divine name. Among more recent poets the exploits of the two Joves became confused, and his character blended with that of his predecessor. The first Jove is obviously the antecedent of the second, but Boccaccio does not know precisely when they lived. The temporal uncertainty caused by his discordant sources returns in the conclusion to his exposition: "De tempore non constat. Sunt tamen qui credant eum Cecropem Atheniensium regem primum fuisse, sed ab hoc vulgata discordat opinio, cum Cecrops fuerit egyptius, et Iuppiter arcas. Alii vero antiquiorem dicunt, nec tamen ullus precisum tempus apponitur, et ideo omictamus" ("Nothing is known about the time [in which he lived]. There are those who believe that he was Cecrops, the first king of the Athenians, but common opinion is discordant about this, because Cecrops was Egyptian, and Jupiter Arcadian. Others say that he was more ancient, but no precise time is attributed, and therefore let us omit it"). ${ }^{130}$ Boccaccio realizes that the precision of the time in which this man lived is essential to his exposition, but he cannot harmonize his dissonant sources. Nevertheless, the relationship that Boccaccio constructs between these two mythic fragments about Jove is one of historical translation. The acts of the second Jove are a part of a different historical context, but they are connected by the poetic imagination to the acts of his predecessor. ${ }^{131}$ In the poetry of the ancients that Boccaccio has at his disposition, Jove is a mixture of these two instantiations along with a third one, who belongs to a later time and a different place.

The third Jove is the most recent mythic instantiation of the divine name and is the adulterous Jupiter whose figure is most notable in classical poetry. He was

${ }^{128}$ This war is said by Theodontius to be the Titanomachy, since he confuses it with Ovid's tale of Leto and Jove, an opinion confirmed by Boccaccio's other favorite modern source, Leontius. But Boccaccio deduces from Ennius's Sacra historia (cited in Lactantius's Divinae institutiones) that the Titanomachy was waged by the third Jove, since that war concerned Saturn, father of the third Jove (Genealogie 4.1.6).

${ }^{129}$ Genealogie 5.1.3.

${ }^{130}$ Genealogie 5.1.4.

${ }^{131}$ Here translatio imperii is seen to take place on the plane of the imagination, although, since the second Jove is deified after his death, the significance of his deification is more cultural than political. A transfer of culture in a broad sense, this translatio civitatis is also connected with translatio studiorum, which describes the transfer of intellectual authority from Greece to medieval Europe via Arabic translators. See n. 93 above.

Speculum 87.3 (July 2012) 
the historical son of Saturn and Ops; ${ }^{132}$ he waged the wars against the Titans and Giants; his brothers were Neptune and Pluto; and his wife and sister was Juno. For Boccaccio he was a man who became king of Crete after Ops sent him to be raised on Mount Ida in order to save him from his father, Saturn, who was murdering all their children in order to keep a pact with his brother Titan that ensured the transition of power to Titan's children. Boccaccio understands from Eusebius that this means Jove was entrusted to Cretus, king of Crete, ${ }^{133}$ and was hidden in a cave on Mount Ida. Once grown, he took revenge on the Titans and freed his parents from captivity:

Hic tandem cum adolevisset, ob captos parentes bellum habuit cum Titanis liberavitque illos. Inde patrem regno expulit, eo quod comperisset eum vite sue insidiari, que supra ubi de Saturno latius dicta sunt; et hinc illi dicunt bellum cum Gigantibus consecutum, quos superatos supposuit montibus.... Deinde orbe subacto cum fratribus imperium partitus est, dato Plutoni Infernorum dominio, Neptuno autem maris, sibi Olympo servato. Et cum iam diu ante Iunonem sororem suam sumpsisset in coniugem, et rex potens factus, glorie avidus, cepit ambire, et non minus astutia quam viribus non solum humanas laudes, sed divinos etiam sibi quesivit honores.

When he had become an adult, he waged war with the Titans on account of his captive parents, and he liberated them. Then he expelled his father from the kingdom when he found out that he was plotting against his life (about which I said enough in the chapter on Saturn). From this point they say that the war with the Giants followed. Once he had conquered them, he buried them with mountains.... Then, having subjugated the world, he divided the empire with his brothers, giving the dominion of the infernal lands to Pluto, the dominion of the sea to Neptune, and saving Olympus for himself. He had long before taken his sister Juno as his wife; and when he had become a powerful king, he began to become ambitious and greedy for glory. So-not less with cunning than with force- he sought not only the praise befitting a human but also the honors given to gods. ${ }^{134}$

The third Jove's connection with his predecessors is presented in a different, more problematic light than the second Jove's connection with the first Jove. The third Jove takes advantage of the tradition that deified ethically virtuous men because of his greed for glory. The first Jove had assumed the status of a god because of the convergence of natural and ethical virtue, whereas the second Jove had been given the name because of his just rule. Although the physical universe did not converge in the process that led to the naming of the second Jove, the third Jove is even further removed from the original convergence of physis and ethos. All the same, he regenerates the political power represented by the name Jove.

\footnotetext{
${ }^{132}$ According to Boccaccio, Saturn was a king who made himself a god by naming his father Coelum (for the heavens) and mother Vesta (for the earth) and having his people worship them. See Genealogie 7.1 for his description of Saturn. Ops was a woman who became worshiped as a goddess because of her association with her father Coelum, her husband and brother Saturn, and her son the third Jove.

${ }^{133}$ See Eusebius, Chronicorum libri duo, ed. Alfred Schoene, 2 vols. (Berlin: Weidmann, 1875; repr., Dublin: Weidmann, 1967), 22.20-25.

${ }^{134}$ Genealogie 11.1.5-6.
} 
Only through such a genealogical reading of the mythic names and narratives can Boccaccio make any sense of what Roman poets meant when they wrote about the exploits of Jove:

Nec suffecit attribuisse illi quod fecerit, quin imo multa ex his que ante eum per plura secula facta fuerant, et potissime eorum duorum temporibus, quos supra Ioves nuncupatos diximus, per nominum abusionem in hunc revocata sunt, nec aliter quam suo evo facta eidem attributa.

It was not sufficient to attribute to him only what he had done but also many of the things that had been done many centuries before him, especially in the times of those two whom we said were called Jove above; by abuse of names these actions were called back for him and attributed to him just as were those things done during his own age. ${ }^{135}$

Not only were the qualities of the first two Joves attributed to the third but also some of the qualities of the Christian God: "multa ad verum Deum ... spectantia" ("many things belonging to the true God"). ${ }^{136}$ This became problematic because the ignari, or "unknowing," also believed the actions of Jove to be those of the true god, including "adulteria, proditiones et bella et huiusmodi" ("the adulteries, the betrayals, the wars, and other such things"). ${ }^{137}$ These misreadings were later inherited by ancient wise men, who recuperated Jove's qualities by interpreting them as having been produced "pro aliquo naturali actu opere nature naturate" ("according to some natural action through the operation of physical nature"). ${ }^{138}$ They reconnect the licentious stories associated with the third Jove to the natural meanings associated with the character of the first. Furthermore, wise men, such as Apuleius, translate the plurality of the pagan gods retraceable to the figure of Jove into a Neoplatonic monotheism: "prudentes voluere deitates illas multis ascriptas diis, potentie unius veri Dei officia esse, existimantes sic per ministros deum agere uti mortales agimus, quod clarissime in libro De dogmate Platonis ostendit Apuleius" ("wise men wanted those divine qualities, which are ascribed to many gods, to be the functions of the power of the one true God, since they thought that God acts, as we mortals act, through his ministers. Apuleius shows this very clearly in his book De dogmate Platonis"). ${ }^{139}$ In natural philosophy the historically distinct figures of the three Joves become a single symbol of the elements of air and fire, which are also associated with the Christian God. Modern re-allegorization is linked to the historical process through which the stories about the divine name came to be.

Instead of reading the figure of Jove as a historical exemplum or as a natural allegory, Boccaccio shows how meaning was compounded within the divine name across time. The meaning of each subsequent name is dependent upon the original historical instance of allegoresis, but it is not a mere imitation or repetition of that meaning. Boccaccio both saves Jove's character from the problematically licentious stories about him and explains how the god's meaning grew out of

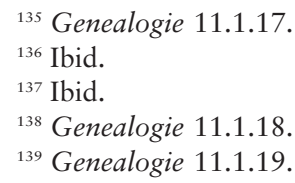

Speculum 87.3 (July 2012) 
historical use and abuse of the original Jove's name. Because of the ubiquity of the character in ancient myth, Boccaccio's explications of the multiple Joves frame how he sees the historical development of mythic meaning. For him Jove was salvageable in the modern Christian era primarily because of his ethical virtue, which was the reason behind the deifications of the first and second Jove. In order to understand the allegorical significance of such figures as Jove in the poetry of more recent antiquity and of Christian modernity, Boccaccio endeavors to separate and contextualize each past instance in which elements were added and taken away from the mythic figure.

Boccaccio's approach to myth in the Genealogie is based upon medieval models of thought, however contradictory, but this does not mean that his is a mere repetition of previous mythographies. Although he is often imprecise and confused in his genealogical expositions, his effort at creating a human, historical context for the creation of myth is strikingly modern. He is fully aware that his distance from antiquity may render his reconstruction an absolute failure, but by feigning a primitive point of view he is able to imagine the motivating factors behind the creations of mythic figures for natural and ethical phenomena. By presenting myth genealogically as a human creation in time, Boccaccio is able to show how meaning persists in both high and low culture across the spectrum of human experience. He separates the understanding of myth as a literary phenomenon from myth as a broadly understood cultural construction, so that even authorities, such as Ovid and Virgil, may be contradicted. His employment of a theory of allegory that allows for temporal and spatial developments in meaning allows him to draw connections between the uses of certain figures in different historical epochs and distant geographical locations (however improperly he might reconstruct them). Beginning with a confused amassment of fragments, Boccaccio follows this principle of temporal and spatial division in order to understand the intentions of diverse epochs when they referred to a myth. His radical historicism in the Genealogie is perhaps the first sign of an anthropology of myth in Western culture, according to which culture is seen to develop in different locations over time and to be preserved haphazardly in the remains of classical poetry. His own time, too, shows its genealogical relation to the past whenever a contemporary poet invokes ancient mythic figures, so that poetic thinking becomes the key to renovating antiquity. The nobility of ancient poetic thought is reborn in the mythic figures of modernity, and myth itself becomes the location of relating (to) the past.

David Lummus is Assistant Professor of Italian at Stanford University (e-mail: dlummus@stanford.edu). 